\title{
Caracterización petrológica y geoquímica de las rocas plutónicas de la Sierra de La Aguada, Provincia de San Luis, Argentina: Implicaciones genéticas con el arco magmático Famatiniano
}

\section{Petrological and geochemical characterization of the plutonic rocks of the Sierra de La Aguada, Province of San Luis, Argentina: Genetic implications with the Famatinian magmatic arc}

\author{
E. Cristofolini $i^{1,2}$, M. Barzola ${ }^{1,2}$, J. Otamendi $^{1,2}$, A. Tibaldi ${ }^{1,2}$, A. Morosini ${ }^{2,3}$, P. Armas ${ }^{1,2}$, \\ G. Camilletti ${ }^{1,2}$ \\ 1 Universidad Nacional de Río Cuarto, Departamento de Geología, Río Cuarto, Ruta 36 Km 601 CP 5800, Córdoba, \\ Argentina. Email: ecristofolini@exa.unrc.edu.ar. ORCID ID: http://orcid.org/0000-0001-9478-7446, http://orcid.org/0000- \\ 0003-3752-8864, http://orcid.org/0000-0003-4653-9143, http://orcid.org/0000-0002-4221-3499, http://orcid.org/0000-0003- \\ 2706-8200, http://orcid.org/0000-0002-9939-2037 \\ 2 Consejo Nacional de Investigaciones Científicas y Técnicas, Argentina. ORCID ID: http://orcid.org/0000-0002-9194-7843 \\ 3 Universidad Nacional de San Luis, Departamento de Geología, San Luis, Ejército de los Andes 950 CP 5700, San Luis, \\ Argentina.
}

\section{RESUMEN}

El presente trabajo expone una síntesis de la geología que comprende al complejo cristalino que constituye la Sierra de La Aguada, provincia de San Luis, Argentina, desde un enfoque basado en las relaciones de campo, los rasgos petrológico-estructurales y las características geoquímicas. Dicha serranía expone un basamento dominado por rocas plutónicas intermedias-máficas de afinidad calcoalcalina y granitoides félsicos peraluminosos, en conjunto intruidas en metamorfitas de bajo a medio grado metamórfico estabilizadas en condiciones de facies de anfibolita. Todo el conjunto litológico ha sido agrupado dentro del denominado complejo El Carrizal-La Aguada. El análisis de las relaciones de campo, la petrografía y la comparación de las características geoquímicas de las rocas plutónicas del área estudiada y aquellas pertenecientes a la suite ordovícica Famatiniana expuestas en la Sierra Grande de San Luis, sugiere una posible relación genética-temporal vinculada al desarrollo del arco magmático Famatiniano.

Palabras clave: granodioritas; geoquímica; arco magmático; ciclo Famatiniano; Sierras Pampeanas.

\section{ABSTRACT}

This study presents a synthesis on the geology of the crystalline complex that constitute the Sierra de la Aguada, San Luis province, Argentine, from an approach based on field relations, petrologic and structural features

Recibido 6 de diciembre de 2016/ Aceptado el 8 de mayo de 2017/ Publicado online el 6 de julio de 2017

Citation / Cómo citar este artículo: E. Cristofolini, M. Barzola, J. Otamendi, A. Tibaldi, A. Morosini, P. Armas \& G. Camilleti (2017). Caracterización petrológica y geoquímica de las rocas plutónicas de la Sierra de LaAguada, Provincia de San Luis, Argentina: Implicaciones genéticas con el arco magmático Famatiniano. Estudios Geológicos 73(1): e065. http://dx.doi.org/10.3989/egeol.42711.440.

Copyright: ( $\odot 2017$ CSIC. This is an open-access article distributed under the terms of the Creative Commons Attribution-Non Commercial (by-nc) Spain 3.0 License. 
and geochemical characteristic. This mountain range exposes a basement dominated by intermediate to mafic calcalkaline igneous rocks and peraluminous felsic granitoids, both emplaced in low to medium grade metamorphic rocks stabilized under low amphibolite facies. All this lithological terrane has been grouped in the El Carrizal-La Aguada Complex. Field relations, petrographic characterization and geochemical comparison of the plutonic rocks from the study area with those belonging to the Ordovician Famatinian suit exposed in the Sierra Grande de San Luis, suggest a genetic and temporal relation linked to the development of the Famatinian magmatic arc.

Keywords: granodiorite; geochemistry; magmatic arc; Famatinian cycle; Sierras Pampeanas.

\section{Introducción}

La provincia geológica de las Sierras Pampeanas Orientales se caracteriza por presentar un basamento ígneo-metamórfico del Precámbrico al Paleozoico inferior a medio, el cual se diferencia estratigráficamente del conjunto de vulcanitas y sedimentitas continentales de edad post-carbonífera, incluyendo depósitos del Mesozoico y Cenozoico (Gordillo \& Lencinas, 1979). El magmatismo preCarbonífero de las Sierras de San Luis (Sierras Pampeanas Orientales), es adjudicado al ciclo orogénico Famatiniano propuesto por Aceñolaza \& Toselli (1976). El ciclo Famatiniano abarca desde el Ordovícico inferior (Tremadociano $\sim 480 \mathrm{Ma}$ ) al Silúrico Llandoveriano (Aeroniense $\sim 440 \mathrm{Ma}$; ver Sato et al., 2003; Ducea et al., 2010; Alasino et al., 2012), siendo uno de los ciclos orogénicos relevantes en el contexto evolutivo Paleozoico de Gondwana occidental. En ese contexto es que las rocas plutónicas de la Sierra de La Aguada aquí estudiadas, podrían ser asociadas a diferentes fases del mencionado ciclo, y en particular correlacionadas con los eventos magmáticos descriptos y datados (490-465 Ma) en la Sierra Grande de San Luis (Sato et al., 2003; Steenken et al., 2008; 2010; Morosini \& Ortiz Suárez, 2010; Morosini et al., 2009; 2017; ver Fig. 1). Teniendo en cuenta la importancia de la Sierra de La Aguada en el marco geotectónico regional, ya que se dispone en el límite geológico entre las unidades que componen el basamento de las Sierras de Córdoba y San Luis, cuyas edades y evoluciones son hasta el momento disímiles, y dada la ausencia de estudios detallados de la misma, esta contribución tiene por objetivo presentar las observaciones petrológicas realizadas en dicha serranía. El estudio fue desarrollado cubriendo por completo el bloque serrano de La Aguada (Figs. 1 y 2), realizando un trabajo petrológico de detalle, delimitando y caracterizando las distintas asociaciones y variedades litológicas, conjuntamente con un estudio de la geoquímica de las rocas plutónicas presentes. El análisis conjunto de la información recolectada, sirve de sustento para evaluar la relación entre los eventos magmáticos y metamórficos dentro del contexto geológico regional. Además aporta al conocimiento del probable ambiente geotectónico y posible edad en el que se desarrolló el magmatismo.

\section{Metodología}

\section{Ubicación geográfica y métodos analíticos}

La Aguada es una pequeña serranía de $22 \mathrm{~km}^{2}$, la cual se encuentra ubicada en la provincia de San Luis, a $10 \mathrm{~km}$ al norte de la localidad de La Punilla, en una posición intermedia entre la Sierra de La Estanzuela y la Sierra de Comechingones (Figs. 1 y 2).

La cartografía realizada se desarrolló mediante la utilización de fotografías aéreas a escala 1:20000 y el análisis multiespectral de imágenes satelitales Landsat y Aster a escala 1:100000 estándar y procesadas con (ENVI, Módulo ASTER DTM), realizando secciones de detalle y modelos topográficos 3D. El mapa geológico a escala 1:50000 fue elaborado en 8 campañas mediante el levantamiento de 6 transectas geológicas, en las cuales se tomaron 42 muestras, además se tomaron datos estructurales mesoscópicos de foliaciones, lineaciones y pliegues. Las rocas fueron estudiadas mediante microscopio óptico en cortes delgados y con lupa binocular en placas pulidas, estando resumidas sus características petrográficas en el Apéndice 1(B) de la versión electrónica. Para la clasificación de las rocas plutónicas se siguieron los criterios de Le Maitre (1989), por esta razón se determinaron las proporciones modales de los minerales, mediante conteo de 1000 puntos en el microscopio petrográfico. El estudio de las rocas metamórficas se basó en los criterios de Spear (1993). En la nomenclatura de los minerales se utilizó las abreviaturas de Kretz (1983). 

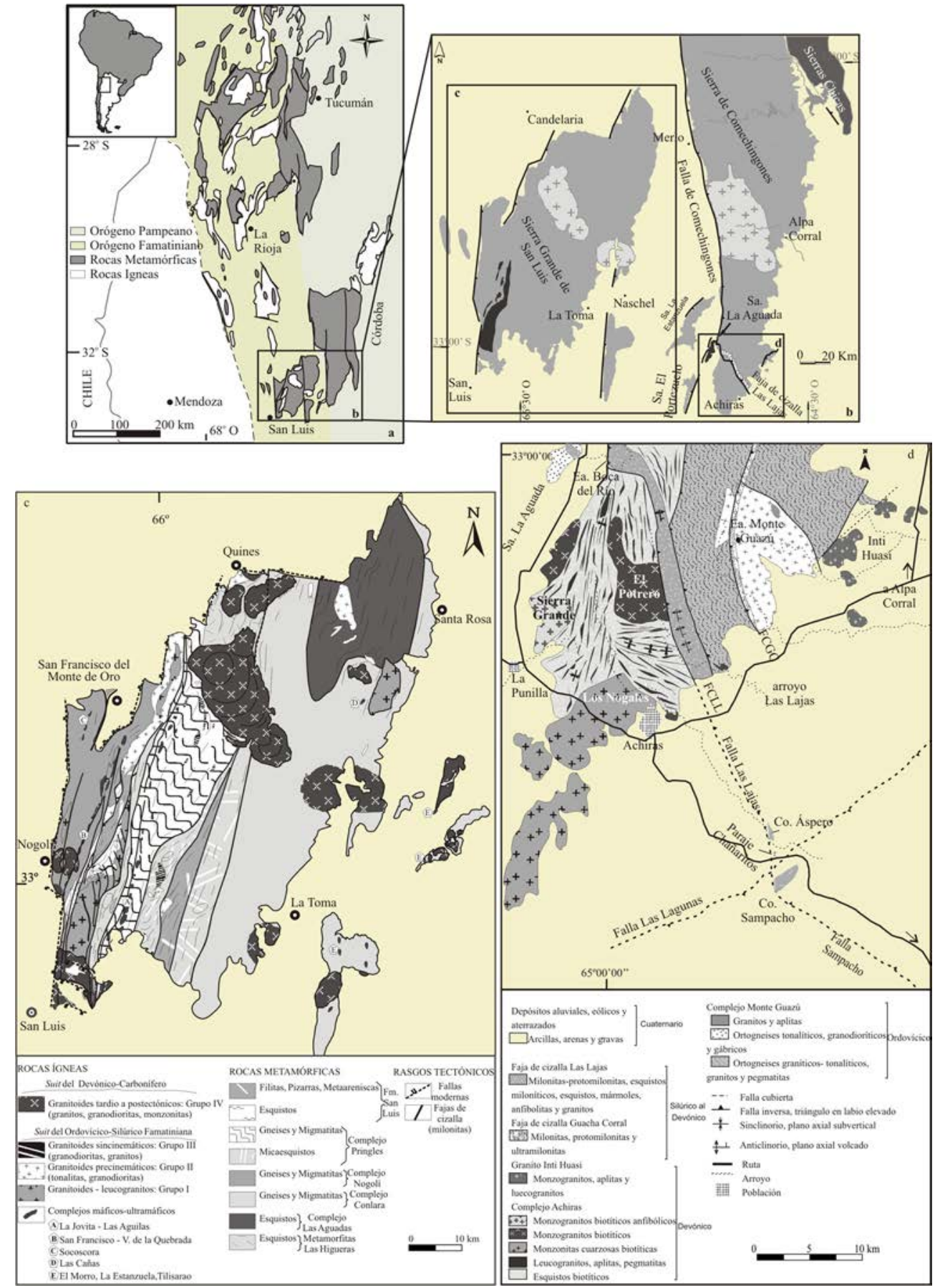

Fig. 1.-a) Mapa geológico simplificado donde se muestra las unidades ígneas y metamórficas de la Provincia Geológica de las Sierras Pampeanas del centro-oeste de Argentina. Se destaca la distribución de los sistemas orogénicos Pampeano y Famatiniano (modificado de Cristofolini et al., 2012). b) Mapa esquemático donde se muestra la Sierra Grande de San Luis destacando las unidades de la suite de rocas plutónicas ordovícicas comparadas en éste trabajo; y el segmento sur de la Sierra de Comechingones, indicando el área estudiada (Sierra de La Aguada). c) Mapa geológico de la Sierra Grande de San Luis mostrando las diferentes unidades y complejos litológicos (modificado de Morosini, 2011; Morosini et al. 2009; 2017). d) Mapa litoestratigráfico simplificado del sur de la Sierra de Comechingones, donde se representan los diferentes complejos litológicos, las fajas de deformación y las estructuras regionales (modificado de Otamendi et al., 2014; Cristofolini et al., 2016). 


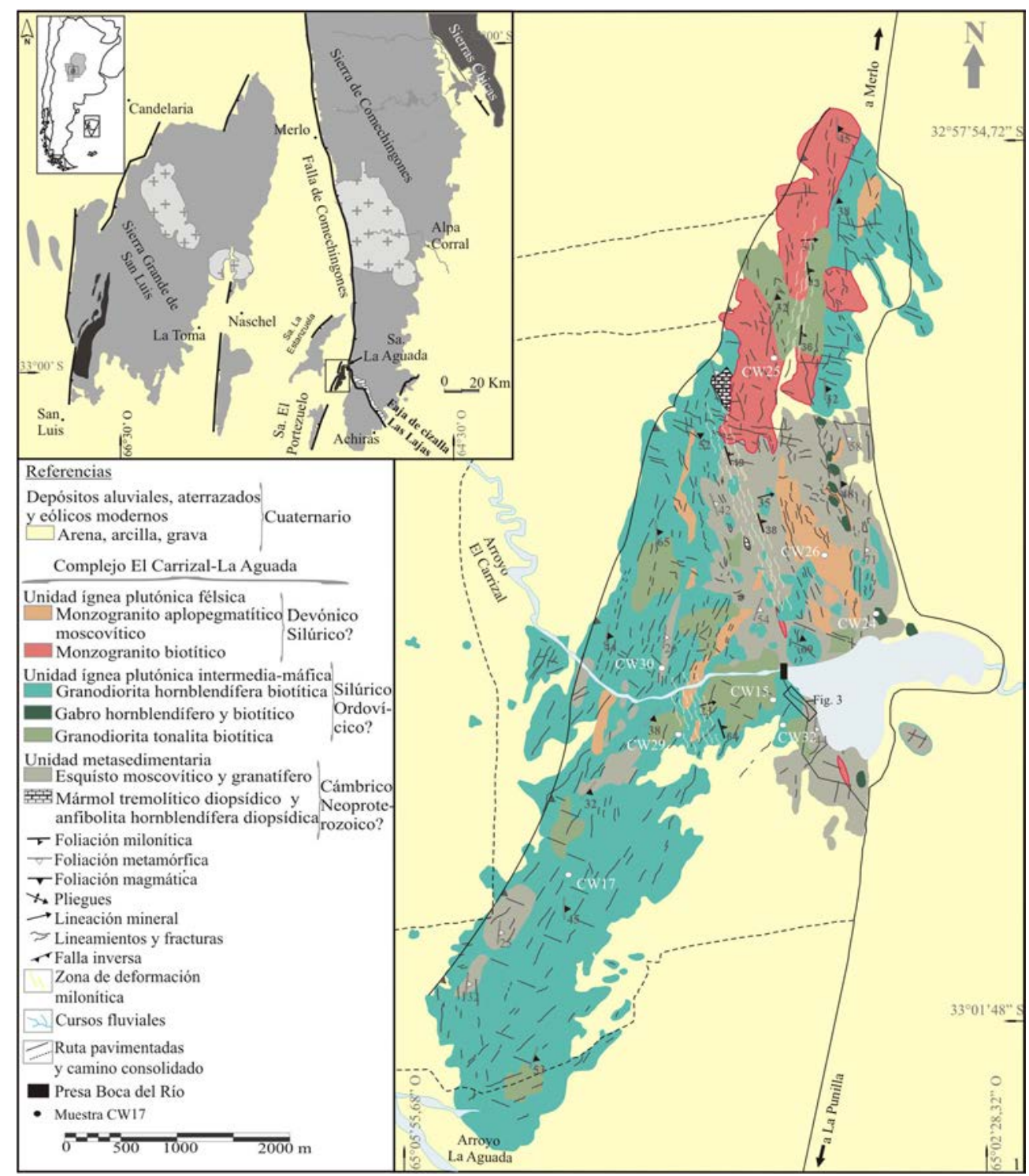

Fig. 2.-Mapa petrológico-estructural de la Sierra de La Aguada, Provincia de San Luis, República Argentina, donde se representan de manera detallada las diferentes asociaciones litológicas y las estructuras, tomado y modificado de Azcurra (2001). Se indica la ubicación de las muestras tomadas para el análisis geoquímico. En el recuadro del extremo superior izquierdo se ubica el área estudiada dentro del contexto geológico de las Sierras Pampeanas del sur de Córdoba y San Luis, destacando en tonos grises obscuros en la Sierra Grande de San Luis la suite de rocas plutónicas ordovícicas.

Para la caracterización química de las rocas plutónicas se efectuó en primera instancia una selección de los ejemplares representativos de cada unidad litoestratigráfica (ver Tabla 1), recolectando por cada muestra $5 \mathrm{~kg}$ de roca fresca. Posteriormente este material fue triturado mediante trituradora de mandíbulas, para luego ser cuarteado y llevado a polvo utilizando molino de anillos de carburotungsteno. El análisis de elementos mayoritarios fue efectuado mediante fluorescencia de rayos $\mathrm{X}$ en la
Universidad de Oviedo, y la cuantificación de elementos trazas mediante la inducción por plasma de Ar acoplado con espectrometría de masas (ICP-MS) en la Universidad de Huelva. Para el análisis de los datos geoquímicos se siguieron las propuestas de Rollison (1993); Debon \& Le Fort (1983); Villaseca et al. (1998) y Frost et al. (2001). Para la comparación de las rocas plutónicas del área con las de la suite ordovícica del arco Famatiniano definidas en la Sierra Grande de San Luis (Figs. 1 y 2) por 


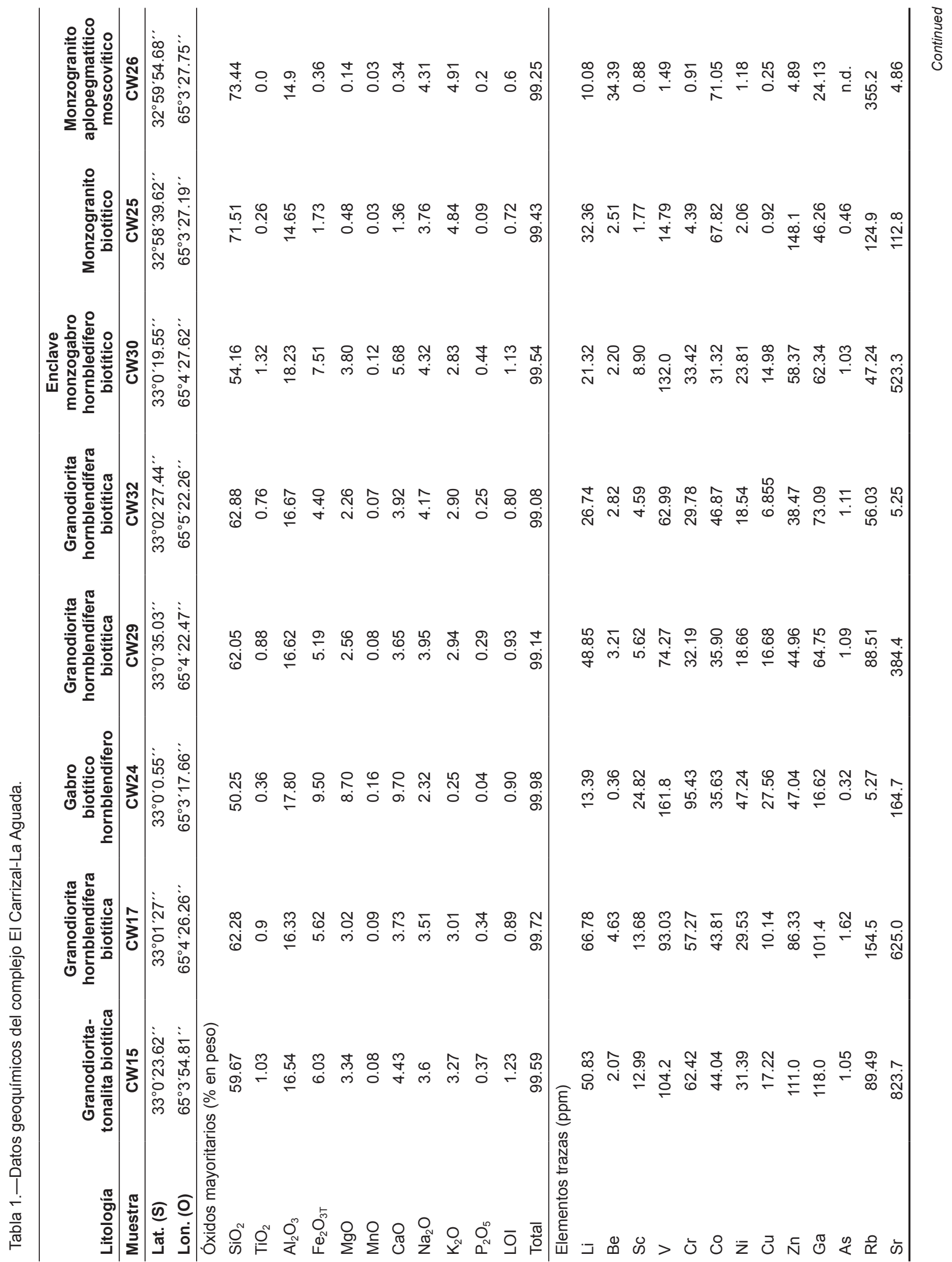




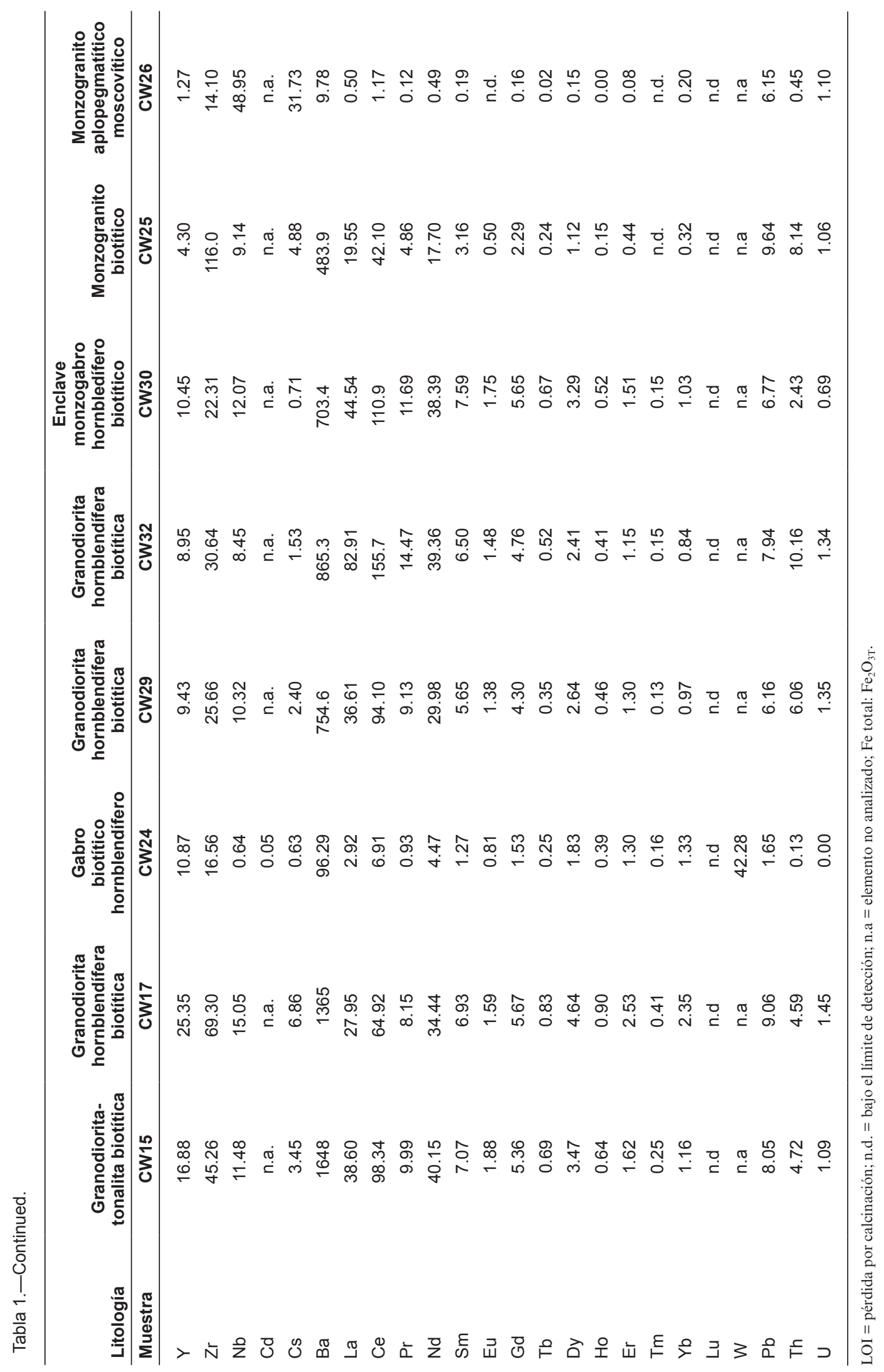


Morosini (2011) y Morosini et al. (2017), se las proyectó conjuntamente en los diagramas que se muestran y analizan en la sección de resultados.

\section{Marco geológico regional}

El marco geológico regional de la zona de interés lo conforman las unidades estratigráficas del sur de la Sierra de Comechingones y el extremo oriental de las Sierras de San Luis, abarcando los Complejos Conlara (Sims et al., 1997) y Achiras (Otamendi et al., 1996; 1998; 2014; ver Fig. 1). El Complejo Conlara es definido por una asociación de esquistos, paragneises y ortogneises, y subordinadamente mármoles, anfibolitas y aplo-pegmatitas graníticas (Ortiz Suárez, 1988; Ortiz Suárez et al., 2009; Sims et al., 1997; von Gosen \& Prozzi, 1998). Este complejo comprende metasedimentos del NeoproterozoicoCámbrico intruidos por granitoides Cámbricos y Ordovícicos (500-470 Ma U/Pb en circones; ver López de Luchi et al., 2002; 2003; Sato et al., 2003; Steenken et al., 2006; 2010; Whitmeyer \& Simpson, 2004; Fig. 1). Dicho conjunto fue polimetamorfizado y deformado durante el Paleozoico inferior a medio, y constituye casi la totalidad del basamento aflorante en la depresión tectónica del río Conlara (serranías de San Felipe, Tilisarao, La Estanzuela, El Morro-Yulto y Portezuelo). Asimismo, forma la mitad oriental de la Sierra Grande de San Luis (Sims et al., 1997). El Complejo Conlara se extiende al oeste hasta la faja de cizalla Río Guzmán, quien actúa como límite occidental (ver Prozzi \& Ramos, 1988; Sims et al., 1997) separándolo de la Fm. San Luis. Por su parte el Complejo Achiras, expuesto en el extremo sur de Sierra de Comechingones, comprende rocas metamórficas de protolitos silicoclásticos y carbonáticos, las que han sido agrupadas en la Unidad India Muerta (Nullo et al., 1995; Otamendi et al., 1996; 1998 2000; 2004; 2014; Fig. 1d). También conforma dicho complejo granitoides anatécticos sin-orogénicos agrupados como Unidad Los Nogales (Fagiano et al., 1993; Fagiano, 2007). El Complejo Achiras, exhibe un límite occidental no visible ya que el mismo es cubierto por sedimentos pedemontanos Cuaternarios, mientras que su límite oriental lo definen las fajas de cizalla Las Lajas y Guacha Corral, quienes lo ponen en contacto tectónico con el Complejo Metamórfico Monte Guazú (Chernicoff \& Ramos, 2003; Otamendi et al., 2014; Fagiano, 2007; Cristofolini et al., 2015; 2016; ver Fig. 1d).

\section{Resultados}

\section{Estratigrafía y petrología de la Sierra de La Aguada}

La Sierra de La Aguada está conformada por un basamento ígneo-metamórfico dominado por un conjunto litológico que exhibe tanto relaciones de campo, como rasgos texturales, mineralógicos y químicos comunes, lo cual permite agruparlo como el denominado Complejo El Carrizal-La Aguada (Azcurra, 2001; Otamendi et al., 1996). Dicho complejo queda conformado por tres unidades litoestratigráficas: 1) unidad metasedimentaria; 2) unidad ígnea plutónica intermedia y máfica y 3) unidad ígnea plutónica félsica (Fig. 2).

La unidad metasedimentaria está conformada por metamorfitas de grado bajo a medio, algunas con evidencias de estratificación sedimentaria. Dentro de dicha unidad se definen esquistos cuarzo-biotíticos y variedades moscovíticas y granatíferas, bancos de anfibolitas hornblendíferas-cuarzo-diopsídicas, anfibolitas hornblendíferas ricas en titanita y escasos lentes de mármoles. La unidad ígnea plutónica intermedia y máfica está constituida por granodioritas hornblendíferas biotíticas y granodioriotas-tonalitas biotíticas, que incluyen ambas a enclaves microgranulares máficos (tonalíticosgábricos) y xenolitos de esquistos. De manera subordinada se encuentran en esta unidad, pequeños lentes de gabros biotíticos hornblendíferos y hornblendíferos piroxénicos. Por su parte, la unidad ígnea plutónica félsica está dominada por cuerpos globosos irregulares y tabulares de monzogranitos biotíticos, diques aplopegmatíticos y pegmatitas de monzogranitos moscovíticos. En términos generales la Sierra de La Aguada está conformada por una secuencia metamórfica de medio a bajo grado intruida por al menos dos series de granitoides, que muestran diferentes relaciones espaciales, genéticas y tal vez temporales.

\section{Unidad metasedimentaria}

Las rocas metamórficas más abundantes y que dominan esta unidad son esquistos cuarzo-biotíticos y de manera subordinada se intercalan algunas variedades de esquistos moscovíticos y/o granatíferos. Los esquistos se presentan en el segmento centro-oriental 
de la sierra, esencialmente en los alrededores de la presa Boca del Río (Fig. 2). Fuera de esta zona solo se encuentran como cuerpos pequeños $(50 \mathrm{~m}$ potencia) elongados y ubicados en la parte central de la serranía, o conformando un cuerpo discreto mayor de $500 \mathrm{~m}$ de longitud situado en el extremo suroeste de la comarca. La paragénesis definida para los esquistos muestra la coexistencia de Bt-Ms-Qtz-Pl \pm (Kfs-Grt). Asimismo, esta unidad se conforma también por bancos menores a $1 \mathrm{~m}$ de potencia de anfibolitas hornblendíferas cuarzo-diopsídicas y/o anfibolitas hornblendíferas ricas en titanita, las cuales localmente se intercalan con lentes de mármoles en parte skarnificados. Estas litologías solo se observan en el extremo noroeste de la sierra y aisladamente en su zona central. La paragénesis definidas en las anfibolitas y mármoles muestra la coexistencia de Hbl-Pl-Qtz \pm (Tr/Act-Di) y Cal/Dol-Tr/Act $\pm(\mathrm{Di})$ respectivamente. El detalle de las descripciones petrológica y caracterización petrográfica de todas las litologías que conforman ésta unidad se puede consultar en el Apendice 1(A), disponible en la versión online de éste artículo.

\section{Unidad ígnea plutónica intermedia y máfica}

Esta unidad constituye el conjunto litológico dominante en la Sierra de La Aguada, conformando más del $80 \%$ de sus afloramientos (Figs. 2 y 3 ). Desarrollan extensas corridas de cuerpos bochiformes elongados, que dominan espacialmente el sector central y sur de la serranía. Está compuesta por granodioritas hornblendífero-biotíticas, gabros biotítico-hornblendíferos y hornblendífero-piroxénicos y granodioritas-tonalitas biotíticas. Además, incluidos en las rocas antes mencionadas, se presentan enclaves microgranulares máficos (gábricos) y xenolitos de esquistos.

\section{Granodioritas hornblendíferas biotíticas}

Estas rocas representan la mayor distribución areal de la unidad, y se disponen como grandes cuerpos $(>100$ $\mathrm{m}$ potencia $\mathrm{y}>500 \mathrm{~m}$ longitud) elongados con su eje mayor orientado en sentido N-S o NE-SO (Figs. 2 y 3 ). Poseen contactos netos o transicionales difusos con las rocas metasedimentarias que las hospedan. Exponen

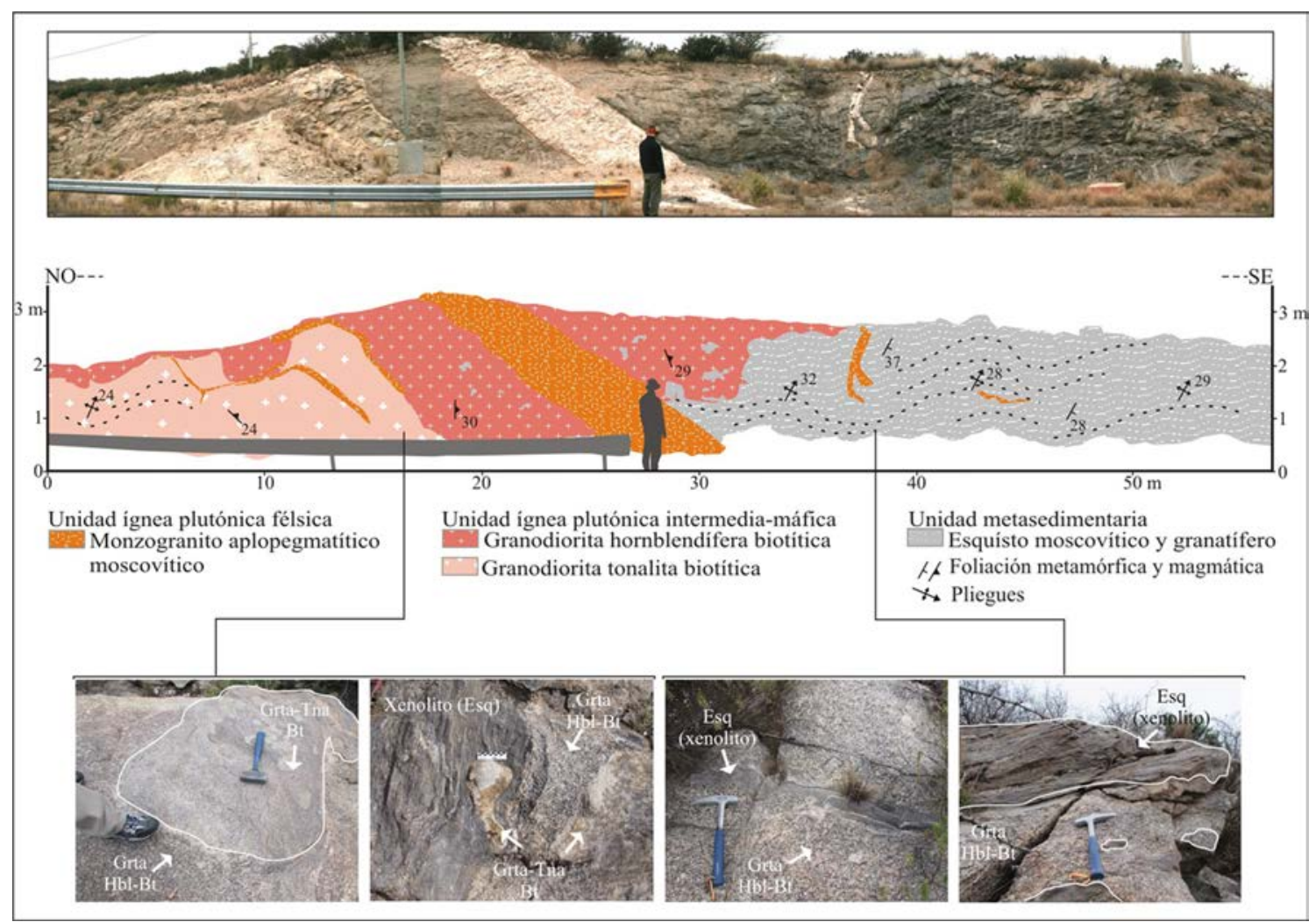

Fig. 3.-Esquema de relaciones de campo entre las diferentes litologías de la zona estudiada. Se muestran los contactos, las relaciones de intrusividad y las estructuras. Grta: granodiorita; Grta-Tn: granodiorita-tonalita; Esq: esquisto. 
relaciones de invasión e inyección sub-concordante con respecto a la foliación de las metasedimentitas, las cuales son englobadas y parcialmente asimiladas quedando como xenolitos (Figs. 3 y 4g). Las granodioritas hornblendíferas biotíticas también están englobando a algunos cuerpos de granodioritas-tonalitas biotíticas, mostrando contactos difusos y localmente exponen enclaves máficos de diversos tamaños. En general son rocas con tonalidades grises a rosadas pálidas y textura porfírica con matriz hipidiomórfica inequigranular de grano grueso (Fig. 3). Se componen de cuarzo, plagioclasa (labradorita-bytownita), feldespato potásico (ortoclasa, microclino) y abundante hornblenda y biotita (Figs. 4g y 4h). Exhiben como accesorios titanita, epidoto, apatito y escasa allanita, magnetita/ilmenita y circón (Apéndice 1(B), disponible en la versión online de éste artículo). Comúnmente presentan una foliación magmática denotada por la orientación de megacristales $(3$ a $7 \mathrm{~cm})$ de feldespato potásico, que se disponen alineados con sus ejes mayores elongados siguiendo una dirección preferencial (Fig. 4g). Asimismo, dicha foliación también se evidencia por la orientación subparalela de enclaves máficos elipsoidales de 15 a $20 \mathrm{~cm}$ de longitud, que generan corredores o bandas ricas en enclaves. La foliación magmática se dispone con rumbo $\mathrm{N} 8^{\circ}$ a $N 26^{\circ}$ y buzamiento moderado de $\sim 36^{\circ}$ al E. Cabe destacar, que las granodioritas son intruidas por diques de monzogranitos biotíticos y aplopegmatíticos moscovíticos, tanto de manera concordante como discordante con respecto a su foliación interna.

Cabe destacar, que en sectores las granodioritas muestran una fuerte deformación dúctil, principalmente en los afloramientos de la margen centro-oriental de la sierra (Fig. 2). Esta deformación desarrolla una fuerte, pero localizada, foliación tipo milonítica, que retrabaja la fábrica magmática original (Figs. 4i y 4j). En estos casos las granodioritas se presentan en afloramientos con patrones angulosos lajosos, de potencia siempre $<20 \mathrm{~m}$ y extensión $<50 \mathrm{~m}$. Internamente la fábrica ígnea es obliterada en parte, con reducción del tamaño de grano generando una fábrica anastomosada grosera. Esta última se muestra como bandas cuarzofeldespáticas elongadas, ahusadas y/o boudinadas, circundadas por folias finas de biotita, hornblenda y cuarzo (Figs. 4i y 4j). En ocasiones los megacristales de feldespato alcalino están aplastados y con morfologías sigmoidales, rodeados por cintas de cuarzo-plagioclasa, láminas flexuradas de biotita y finos prismas de hornblenda tremolitizada. La disposición espacial de ésta foliación milonítica es coincidente con la fábrica magmática original, con rumbo $\mathrm{N} 10^{\circ}$ a N $20^{\circ}$ y buzamiento de $\sim 32^{\circ}$ al $\mathrm{E}$.

\section{Granodioritas-tonalitas biotíticas}

Esta litología solo se presenta localizadamente y en baja proporción (Figs. 2 y 3). Se dispone en el extremo noroeste del área, intruyendo de manera concordante a esquistos y mármoles y/o siendo intruida discordantemente por monzogranitos. También se define en pedanías a la presa Boca del Río, donde es intruida discordantemente por las granodioritas hornblendíferas biotíticas (Fig. 2). En este último caso se observan contactos discordantes difusos. Estas rocas conforman cuerpos globosos subredondeados, siempre elongados con su eje mayor orientado N-S y dimensiones de $\sim 50 \mathrm{~m}$ de potencia $\mathrm{y}>500 \mathrm{~m}$ longitud. Normalmente son heterogéneas de grano medio, con tonalidades que varían en dominios leucocráticos de tonos rosados a melanocráticos con tonos grises, asociado esto con el incremento modal de biotita (Figs. 3 y 5a). Muestran una textura hipidiomórfica inequigranular, siendo porfírica solo localizadamente y se componen de cuarzo, plagioclasa (andesina-labradorita) y variada proporción de feldespato potásico (microclino y ortoclasa). Como accesorio domina biotita y escasa proporción de apatito, circón y magnetita/ilmenita (Figs. 5a, 5b y Apéndice 1(B)). También, exhiben una foliación magmática difusa localizada dada por la orientación de megacristales (2 a $3 \mathrm{~cm}$ ) de plagioclasa y/o feldespato potásico. Dicha foliación se dispone con un rumbo $\mathrm{N} 12^{\circ}$ a N $22^{\circ}$ y buzamiento moderado de $\sim 41^{\circ}$ al E. Siempre las granodioritas-tonalitas presentan enclaves máficos pequeños y son intruidas discordantemente por aplopegmatítas monzograníticas.

Es necesario remarcar que en algunos segmentos de la comarca, esta litología se presenta con una intensa deformación dúctil-frágil sobreimpuesta, que oblitera parcial y/o totalmente la fábrica ígnea (Figs. 5c y 5d). En este último caso la roca muestra una reducción generalizada del tamaño de grano y el desarrollo de una foliación milonítica penetrativa. A escala de afloramiento se exponen como bancos lajosos elongados en sentido N-S, de 
(a)

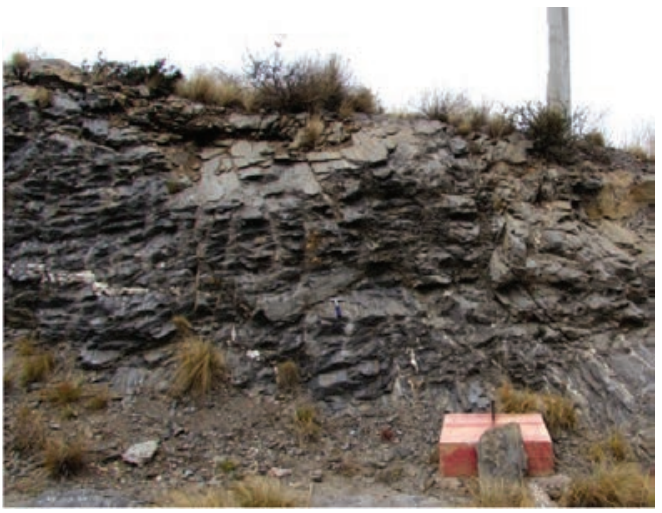

(c)

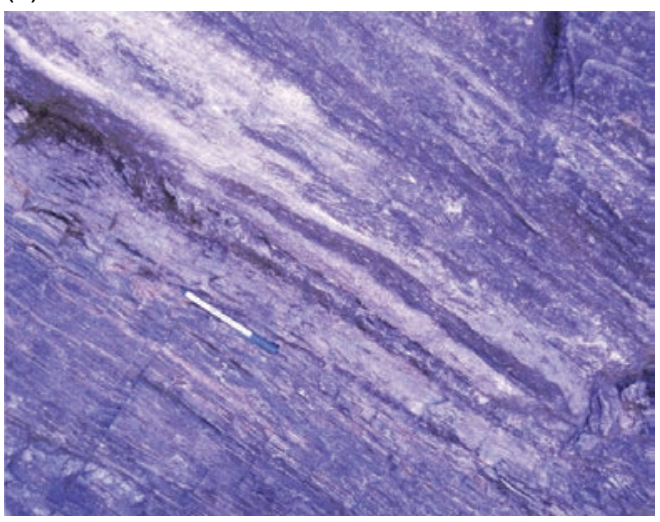

(e)

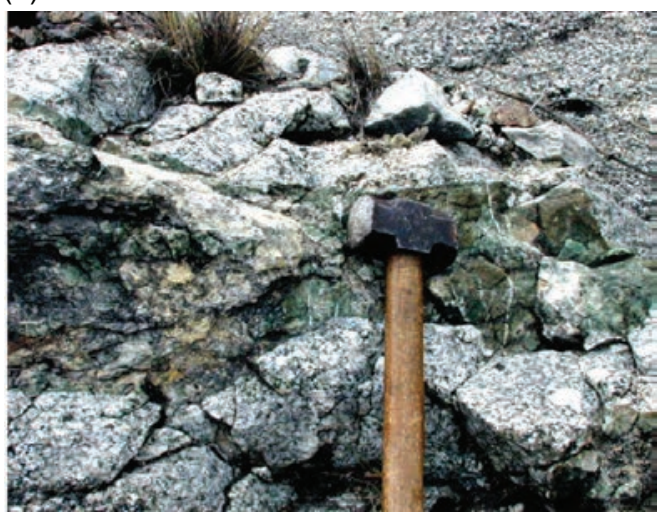

(b)

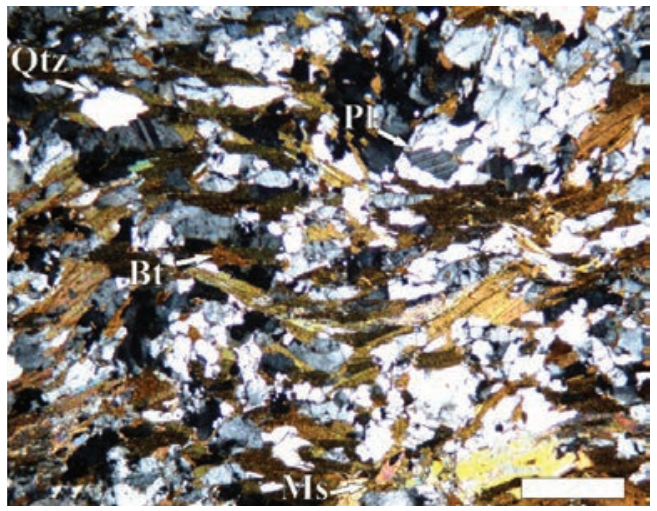

(d)

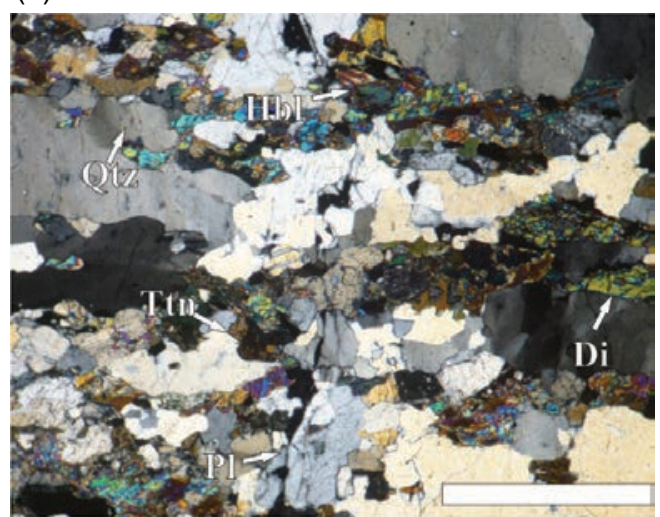

(f)

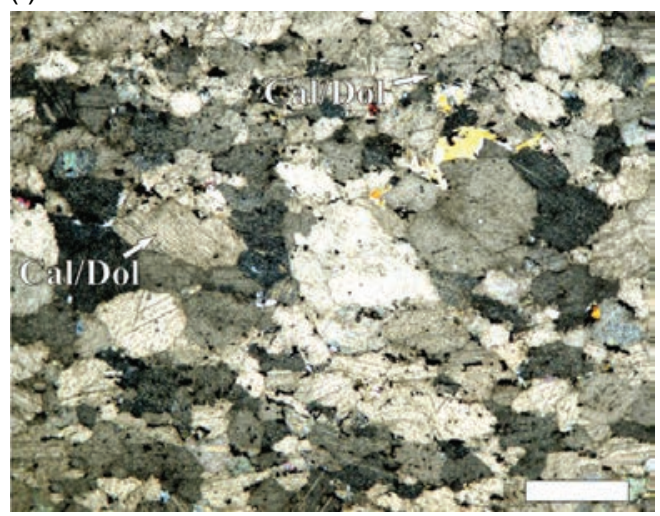

Fig. 4.-a) Foto de afloramiento de esquisto biotítico-moscovítico, donde se muestra la morfología de cuerpos subangulosos foliados, con un marcado plegamiento de escala métrica. La fotografía se dispone con vista al S. b) Fotomicrografía a nicoles cruzado de esquisto biotítico-moscovítico, indicando las fases minerales predominantes y la estructura foliada fina. c) Foto de afloramiento de anfibolita hornbléndica donde se denota un marcado bandeado composicional. d) Fotomicrografía a nicoles cruzados de anfibolita, destacando la textura granonematoblástica y el bandeado característico. e) Foto de afloramiento de mármol, mostrando la marcada alteración de las rocas y la fábrica deformacional que afecta localmente a las mismas. f) Fotomicrografía a nicoles cruzados de mármol donde se observan las fases minerales dominantes. g) Foto de afloramiento de granodiorita hornblendífera biotítica, donde se observa el patrón de afloramiento subredondedo. Se destaca además la presencia de xenolitos de esquistos parcialmente asimilados, y el desarrollo de megacristales de feldespato alcalino caracterizando a la textura porfírica localizada. h) Fotomicrografía a nicoles cruzados de granodiorita hornblendífera biotítica, mostrando la textura hipidiomórfica típica, y las fases accesorias características (HblTtn-Bt). i) Foto de afloramiento de granodiorita hornblendífera biotítica con sobreimposición de una foliación milonítica penetrativa. Se muestra la orientación y aplastamiento generalizado de las fases minerales, y el desarrollo de venas leucocráticas con flexuramiento y boudinado localizado. j) Fotomicrografía a nicoles cruzados de granodiorita parcialmente milonítizada, destacando el aplastamiento y la recristalización de las fases minerales. Piqueta $30 \mathrm{~cm}$; masa $30 \mathrm{~cm}$; moneda $2 \mathrm{~cm}$; barra de escala $1 \mathrm{~mm}$. 
(g)

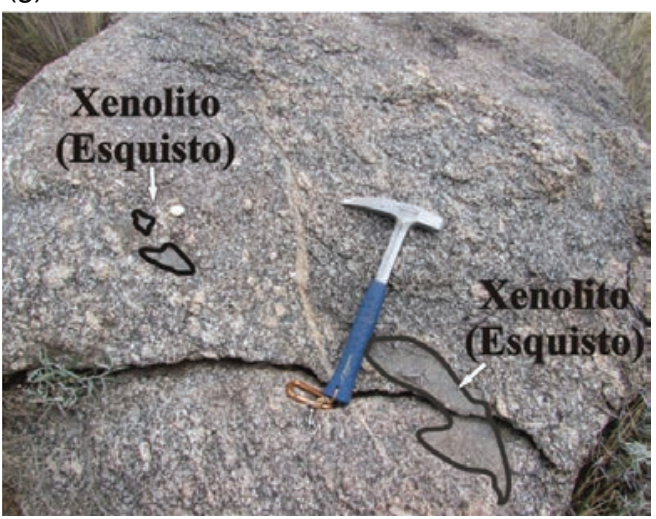

(i)

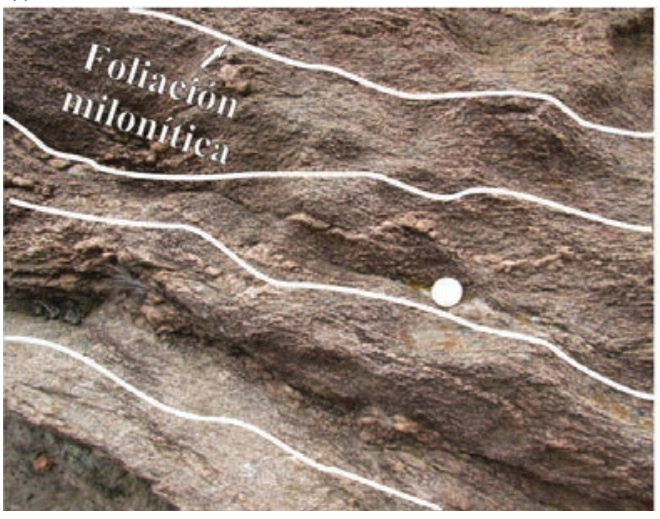

(h)

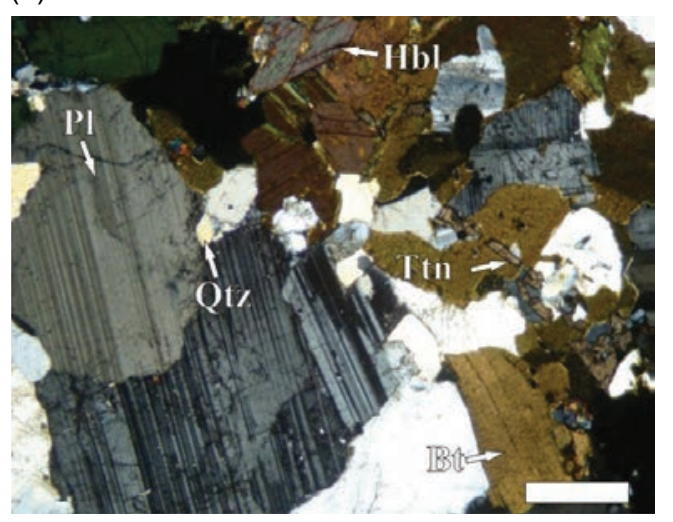

(j)

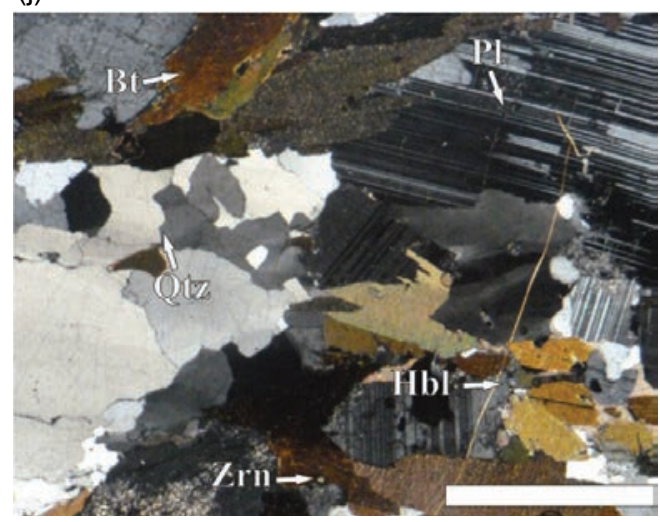

Fig. 4.-Continues. a) Foto de afloramiento de esquisto biotítico-moscovítico, donde se muestra la morfología de cuerpos subangulosos foliados, con un marcado plegamiento de escala métrica. La fotografía se dispone con vista al S. b) Fotomicrografía a nicoles cruzado de esquisto biotítico-moscovítico, indicando las fases minerales predominantes y la estructura foliada fina. c) Foto de afloramiento de anfibolita hornbléndica donde se denota un marcado bandeado composicional. d) Fotomicrografía a nicoles cruzados de anfibolita, destacando la textura granonematoblástica y el bandeado característico. e) Foto de afloramiento de mármol, mostrando la marcada alteración de las rocas y la fábrica deformacional que afecta localmente a las mismas. f) Fotomicrografía a nicoles cruzados de mármol donde se observan las fases minerales dominantes. g) Foto de afloramiento de granodiorita hornblendífera biotítica, donde se observa el patrón de afloramiento subredondedo. Se destaca además la presencia de xenolitos de esquistos parcialmente asimilados, y el desarrollo de megacristales de feldespato alcalino caracterizando a la textura porfírica localizada. h) Fotomicrografía a nicoles cruzados de granodiorita hornblendífera biotítica, mostrando la textura hipidiomórfica típica, y las fases accesorias características (HblTtn-Bt). i) Foto de afloramiento de granodiorita hornblendífera biotítica con sobreimposición de una foliación milonítica penetrativa. Se muestra la orientación y aplastamiento generalizado de las fases minerales, y el desarrollo de venas leucocráticas con flexuramiento y boudinado localizado. j) Fotomicrografía a nicoles cruzados de granodiorita parcialmente milonítizada, destacando el aplastamiento y la recristalización de las fases minerales. Piqueta $30 \mathrm{~cm}$; masa $30 \mathrm{~cm}$; moneda $2 \mathrm{~cm}$; barra de escala $1 \mathrm{~mm}$.

potencia $<10 \mathrm{~m}$ y extensión $>200 \mathrm{~m}$. Cuando la transformación de la fábrica ígnea es total, dichas rocas son clasificadas como milonitas s.l., aunque en algunos trabajos regionales a rocas similares se las han clasificado como ortogneises protomiloníticos. Internamente la fábrica ígnea es remplazada por una matriz metamórfica granolepidoblástica a porfiroclástica de grano fino $(<1 \mathrm{~mm})$, en la cual se define una foliación anastomosada. Esta estructura está representada por cintas cuarzo-feldespáticas finas elongadas, alternantes con otras dominadas por biotita-cuarzo-moscovita, ambas englobando a cristales de feldespatos (Figs. 5c y 5d). Estos últimos conforman porfiroclastos de morofologías sigma o complejas, que muestran intenso aplastamiento y desgarres. En conjunto la foliación milonítica se presenta con rumbo $\mathrm{N}^{\circ}$ a $\mathrm{N} 16^{\circ}$ y buzamiento de $\sim 39^{\circ}$ al E. En los casos donde la fábrica milonítica domina, se reconocen pliegues antiformes y sinformes asimétricos e inclinados con vergencia al O-SO, cuyas longitudes de onda varían de 0,4 a $1 \mathrm{~m}$. También se observan pliegues asimétricos e 
(a)

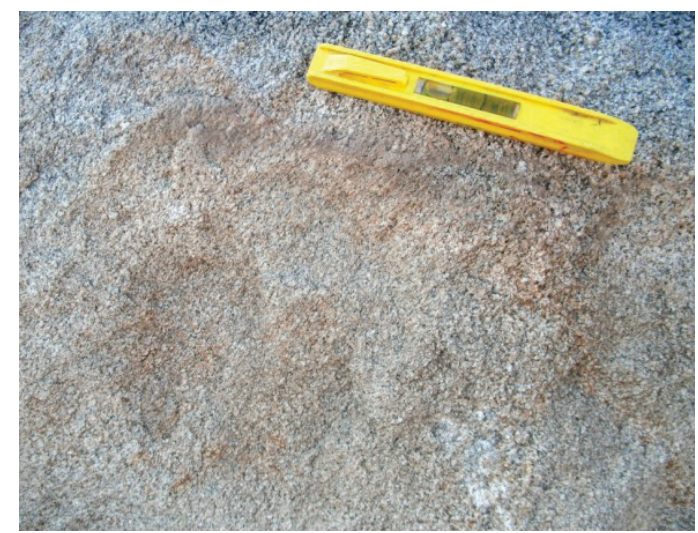

(c)

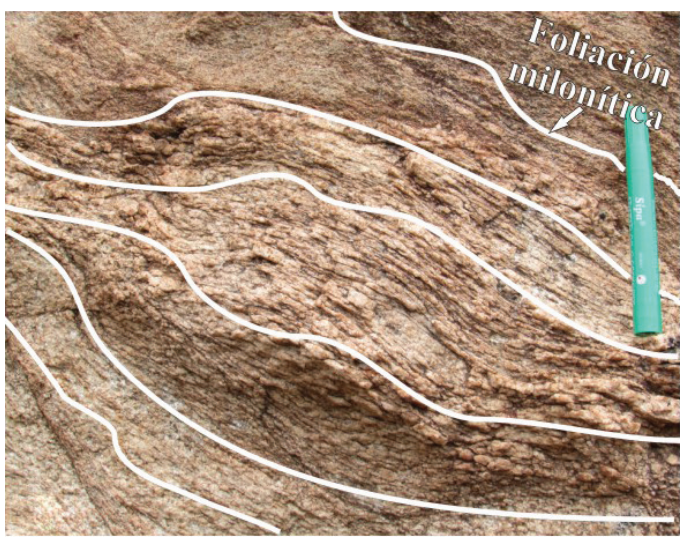

(e)

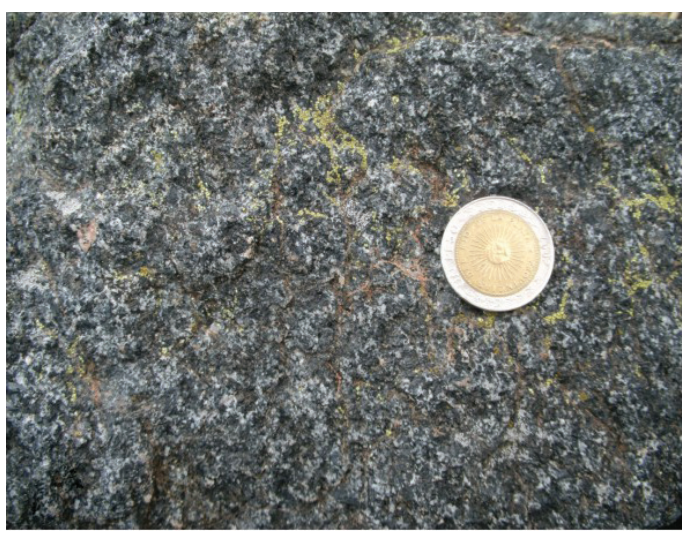

(b)

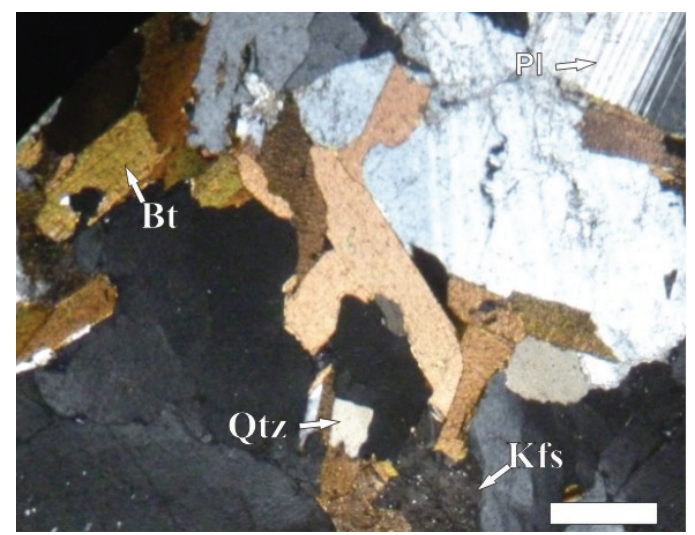

(d)

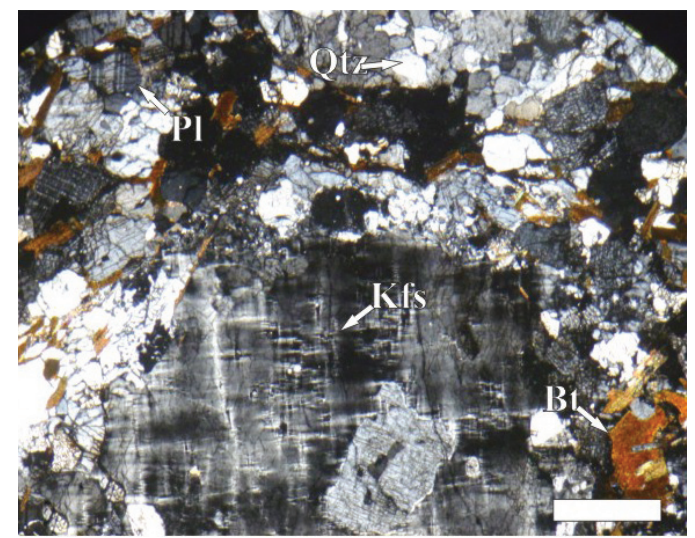

(f)

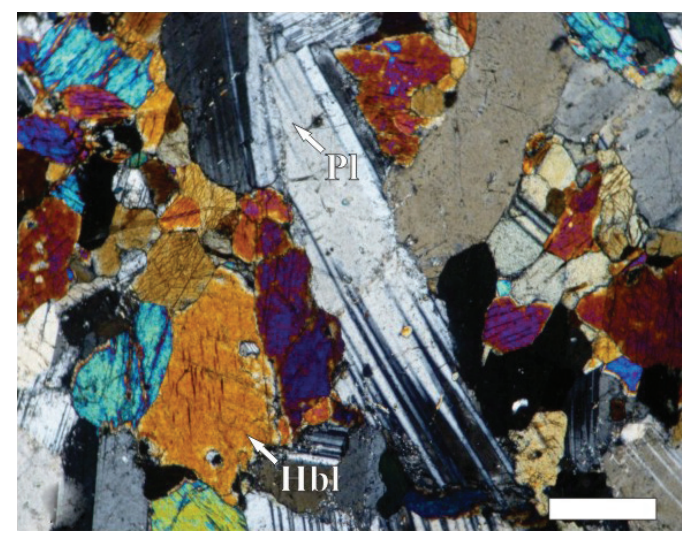

Fig. 5.-a) Foto de afloramiento de granodiorita-tonalita biotítica, mostrando la textura de grano medio y la fábrica ígnea característica. b) Fotomicrografía a nicoles cruzados de granodiorita-tonalita biotítica mostrando la textura hipidiomórfica dominante. c) Foto de afloramiento de granodiorita-tonalita biotítica con una marcada milonitización sobreimpuesta. Se muestra la foliación milonítica anastomosada penetrativa. d) Fotomicrografía a nicoles cruzados de granodiorita-tonalita biotítica milonitizada, mostrando la fabrica milonítica característica. Se destaca la presencia de porfiroclasto de feldespato alcalino y una matriz con marcada recristalización y reducción del tamaño de grano. e) Foto de afloramiento de gabro hornbléndico, con la textura granular de grano medio característica. f) Fotomicrografía a nicoles cruzados de gabro mostrando la relación texural entre las fases $\mathrm{Pl}-\mathrm{Hbl}$ y su arreglo textural hipidiomórfico. g) Foto de afloramiento de monzogranito biotítico exponiendo el patrón de afloramiento subredondeado y bochiforme dominante. h) Foto de afloramiento de monzogranito aplopegmatítico moscovítico, intruido de manera discordante en esquistos. Se destaca sus contactos rectos netos y su variación del tamaño de granos de núcleo a borde. Piqueta $30 \mathrm{~cm}$; nivel $15 \mathrm{~cm}$; marcador $15 \mathrm{~cm}$; moneda $2 \mathrm{~cm}$; barra de escala $1 \mathrm{~mm}$. 
(g)

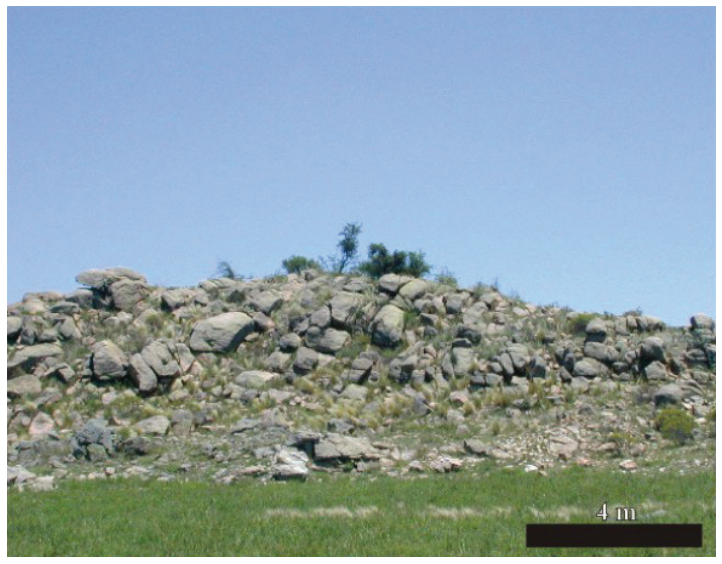

(h)

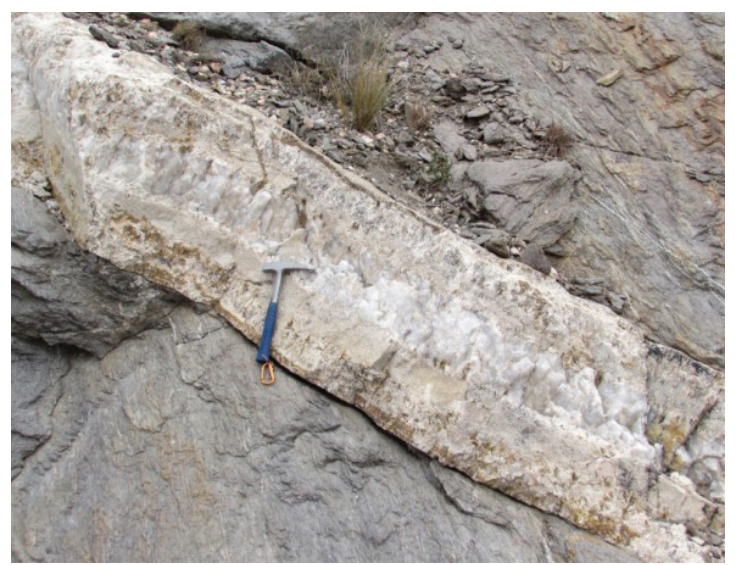

Fig. 5.-Continues. a) Foto de afloramiento de granodiorita-tonalita biotítica, mostrando la textura de grano medio y la fábrica ígnea característica. b) Fotomicrografía a nicoles cruzados de granodiorita-tonalita biotítica mostrando la textura hipidiomórfica dominante. c) Foto de afloramiento de granodiorita-tonalita biotítica con una marcada milonitización sobreimpuesta. Se muestra la foliación milonítica anastomosada penetrativa. d) Fotomicrografía a nicoles cruzados de granodiorita-tonalita biotítica milonitizada, mostrando la fabrica milonítica característica. Se destaca la presencia de porfiroclasto de feldespato alcalino y una matriz con marcada recristalización y reducción del tamaño de grano. e) Foto de afloramiento de gabro hornbléndico, con la textura granular de grano medio característica. f) Fotomicrografía a nicoles cruzados de gabro mostrando la relación texural entre las fases PI-Hbl y su arreglo textural hipidiomórfico. g) Foto de afloramiento de monzogranito biotítico exponiendo el patrón de afloramiento subredondeado y bochiforme dominante. h) Foto de afloramiento de monzogranito aplopegmatítico moscovítico, intruido de manera discordante en esquistos. Se destaca sus contactos rectos netos y su variación del tamaño de granos de núcleo a borde. Piqueta $30 \mathrm{~cm}$; nivel $15 \mathrm{~cm}$; marcador $15 \mathrm{~cm}$; moneda $2 \mathrm{~cm}$; barra de escala $1 \mathrm{~mm}$.

inclinados con vergencia al $\mathrm{SO}$, pero con longitud de onda de 2 a $5 \mathrm{~m}$. En todos los casos la dirección media de ejes axiales es de $\mathrm{N} 162^{\circ}$ y su inmersión es de $16^{\circ}$.

\section{Gabros biotíticos-hornblendíferos y hornblendíferos-piroxénicos}

Los gabros s.l. afloran aislados en la margen centro oriental de la serranía (Fig. 2). Se presentan como cuerpos lenticulares a ovoidales, elongados con sus ejes mayores orientados en sentido NO-SE. Conforman afloramientos pequeños de potencias que no superan los $20 \mathrm{~m}$ y longitudes menores a 200 $\mathrm{m}$, siempre en relación de yacencia intrusiva neta discordante con las metamorfitas (Fig. 2). En sentido amplio, el conjunto de afloramientos de gabros forman una faja de cuerpos pequeños y desmembrados. Los gabros s.l exhiben morfologías subredondeadas, con tonalidades verdes a grises oscuras, y textura inequigranular hipidiomórfica, siendo subofítica intersectal en ocasiones (Figs. 5e y 5f). Los gabros biotítico-hornblendíferos se componen de plagioclasa (bytownita), hornblenda y biotita, mientras que tremolita-actinolita, clorita y magnetita/ilmenita son escasos. En tanto los gabros hornblendífero-piroxénicos están dominados por plagioclasa (bytownita), hornblenda y clinopiroxeno (augita-diópsido), y exigua tremolita-actinolita, cuarzo y apatita. Estas rocas son masivas, aunque en sectores ligados a los bordes de los cuerpos muestran una estructura de deformación dúctil esquistosa y anastomosada, que afecta no solo al cuerpo gábrico sino también a la roca de caja. En estos sitios se observa la elongación y aplastamiento de los minerales máficos (Hbl-Px) siendo estos rodeados y englobados por una matriz de grano fino dominada por Pl-Qtz; Pl-Bt-Tr/ Ac-Chl. Dicha estructura foliada se dispone N-S y con buzamiento $>75^{\circ} \mathrm{E}$.

\section{Unidad ígnea plutónica félsica}

Esta unidad se presenta en moderada proporción, comprendiendo afloramientos aislados. Está dominada por cuerpos globosos subredondeados y/o tabulares, que afloran con mayor volumen en el sector norte y centro-este de la serranía, aunque su presencia es ubicua, intruyendo a todas las unidades 
litológicas (Fig. 2). Esta unidad se constituye de cuerpos de monzogranitos biotíticos y diques aplopegmatíticos de monzogranitos moscovíticos.

\section{Monzogranitos biotíticos}

Se presentan como cuerpos aislados de morfología ovoide globoso y elongados en sentido NO-SE. Son pequeños $(<300 \mathrm{~m}$ potencia; $<500 \mathrm{~m}$ longitud), aunque hay ejemplos de cuerpos mayores que superan los $400 \mathrm{~m}$ de potencia y $1200 \mathrm{~m}$ de longitud (Figs. 2 y $5 \mathrm{~g}$ ). En todos los casos se disponen con contactos netos, intruyendo de manera subconcordantes a discordante con respecto a la foliación magmática y/o metamórfica del encajante. En los cuerpos mayores se observan septos (xenolitos) $<5 \mathrm{~m}$ de potencia de esquistos (Fig. 2). Asimismo, son comunes las intrusiones de aplopegmatoides monzograníticos moscovíticos que cortan discordantemente a los cuerpos mayores. Los monzogranitos biotíticos son de tono rosado a blanquecino, grano medio y de textura inequigranular hipidiomórfica. Se componen de cuarzo, plagioclasa (albita-oligoclasa), feldespato alcalino (microclino, ortoclasa) y biotita, y en baja proporción moscovita, apatita y circón (Apéndice 1(B)). Ocasionalmente presentan epidoto y granate. Internamente muestran la orientación de láminas de biotita de manera aislada, lo que define una foliación magmática imperfecta, cuya orientación indica rumbos de $\mathrm{N} 8^{\circ}$ a N $15^{\circ}$ y buzamiento de $\sim 32^{\circ}$ al E. En ocasiones son afectados por una fuerte deformación dúctil que oblitera parcialmente la fábrica magmática.

\section{Aplopegmatitas y pegmatitas monzograníticas moscovíticas}

Estas litologías se presentan de manera errática intruyendo subconcordante a discordante a la estructura interna de todos los litotipos dominantes de la serranía. Los cuerpos de mayores dimensiones aparecen concentrados en el sector central y oriental de la zona (Figs. 2, 3 y $5 \mathrm{~h}$ ), cconforman enjambres de diques o diques aislados de dimensiones variables, siendo los más comunes de 1 a $3 \mathrm{~m}$ de potencia y longitudes que exceden los $150 \mathrm{~m}$. Presentan formas tabulares a lenticulares elongados y con extremos ahusados. Muestran contactos netos, rectos $\mathrm{y} / \mathrm{u}$ ondulados sin evidencias de borde de reacción con el encajante. En muchos casos han sido plegadas con ángulos abiertos y afectados por deformación dúctil localizada. Presentan zonación textural con núcleos aplíticos o micrograníticos de monzogranitos moscovíticos y bordes pegmatíticos con desarrollo de cristales de cuarzo lechoso, moscovita, plagioclasa (oligoclasa) y feldespato potásico (microclino) de hasta $30 \mathrm{~cm}$ de longitud (Figs. 3 y 5h). También exhiben zonación inversa, con feldespato potásico y cuarzo de grano grueso en el núcleo y bordes, y textura aplítica o microgranítica de grano fino en el borde. También se presentan cuerpos de textura pegmatítica generalizada, dominados por grandes cristales con intercrecimiento de feldespato alcalino y cuarzo, y en menor proporción plagioclasa y moscovita (Apéndice 1(B)). En todos los casos se componen de cuarzo, feldespato alcalino (microclino), plagioclasa (oligoclasa), moscovita, turmalina y granate.

\section{Geoquímica de las rocas plutónicas de Sierra de la Aguada}

\section{Clasificación de las rocas}

Las rocas ígneas de la Sierra de La Aguada fueron clasificadas considerando sus características geoquímicas, pero teniendo siempre en cuenta sus características petrológicas y sus relaciones de yacencia. En primer lugar para la clasificación geoquímica sin distinción de serie, se utilizó la propuesta de De La Roche (1992). Los granitoides intermedios (granodioritas hornblendíferas biotíticas y granodioritastonalitas biotíticas: muestras $\mathrm{CW} 15 ; 17 ; 29 ; 32$; ver Tabla 1) son clasificados como granodiorita s.s. En tanto, el enclave máfico (hornblendíferos biotíticos: muestra CW30; ver Tabla 1) es clasificado como monzogabro cuarzoso (Fig. 6a), mientras que las rocas básicas (gabro biotíticos hornblendífero: muestra CW24; ver Tabla 1) se catalogan en coherencia con la descripción y clasificación modal como gabros cuarzosos. Por otra parte, los granitoides félsicos (monzogranitos biotíticos y aplítico moscovítico: muestras CW25; 26; ver Tabla 1), independientemente de su yacencia, corresponden a monzogranitos s.s. Otras observaciones relevantes respecto de estos litotipos se perciben mediante la clasificación química de rocas graníticas propuesta por Frost et al. (2001; Figs. 6b, 6c y 6d). Se evidencia que todos los granitoides analizados son magnesianos (Fig. 6b), y 

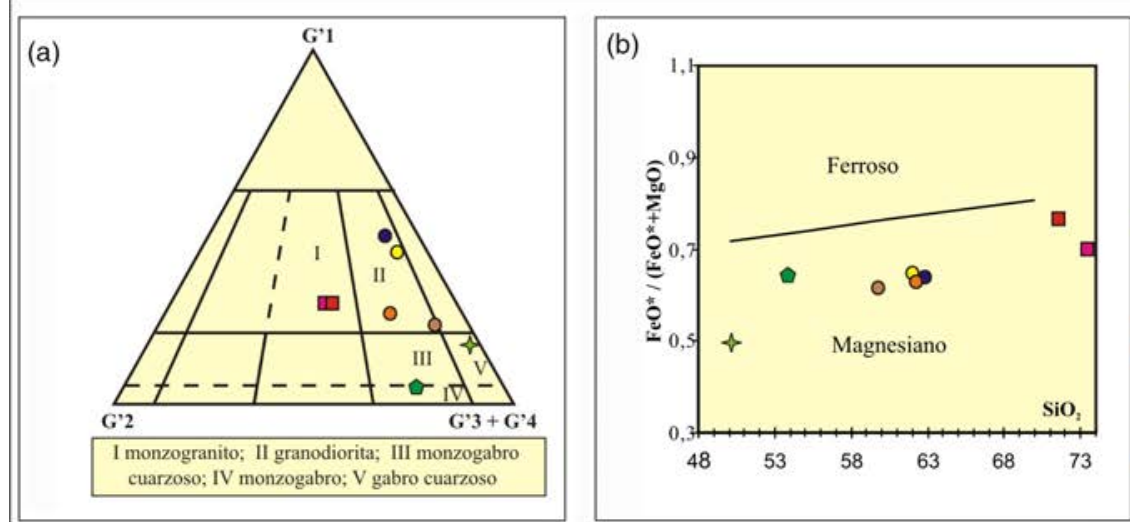
$\underline{\text { Rocas igneas Sierra de }}$
La Aguada
CW 32
(Granodiorita hornblendifera biotítica)
CW 29
(Granodiorita hornblendifera biotitica)
CW 17
(Granodiorita hornblendifera biotitica)
CW 15
(Granodiorita-tonalita biotitica)
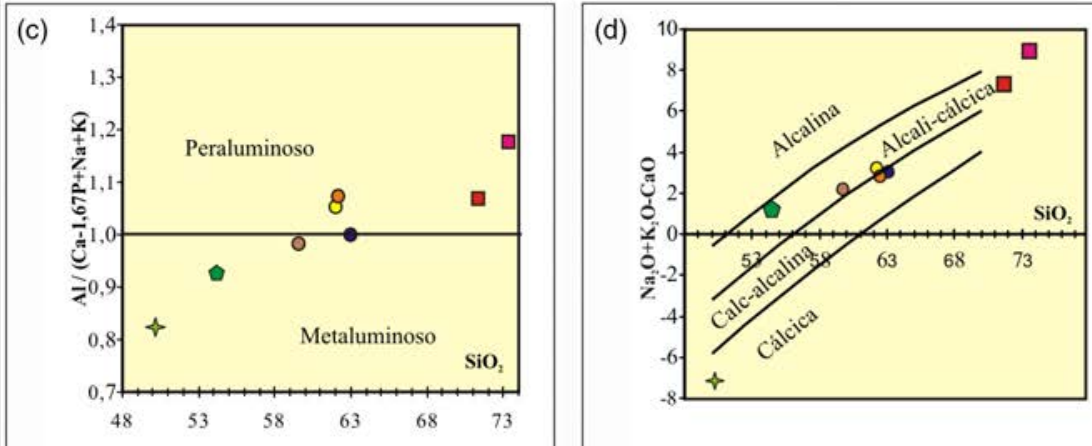

CW 25

(Monzogranito biotítico)

CW 26

(Monzogranito

aplopegmatítico moscovítico)

CW 30

Enclave monzogabro

hornbledifero biotítico)

$\downarrow$ CW 24

(Gabro biotítico hornblendifero)
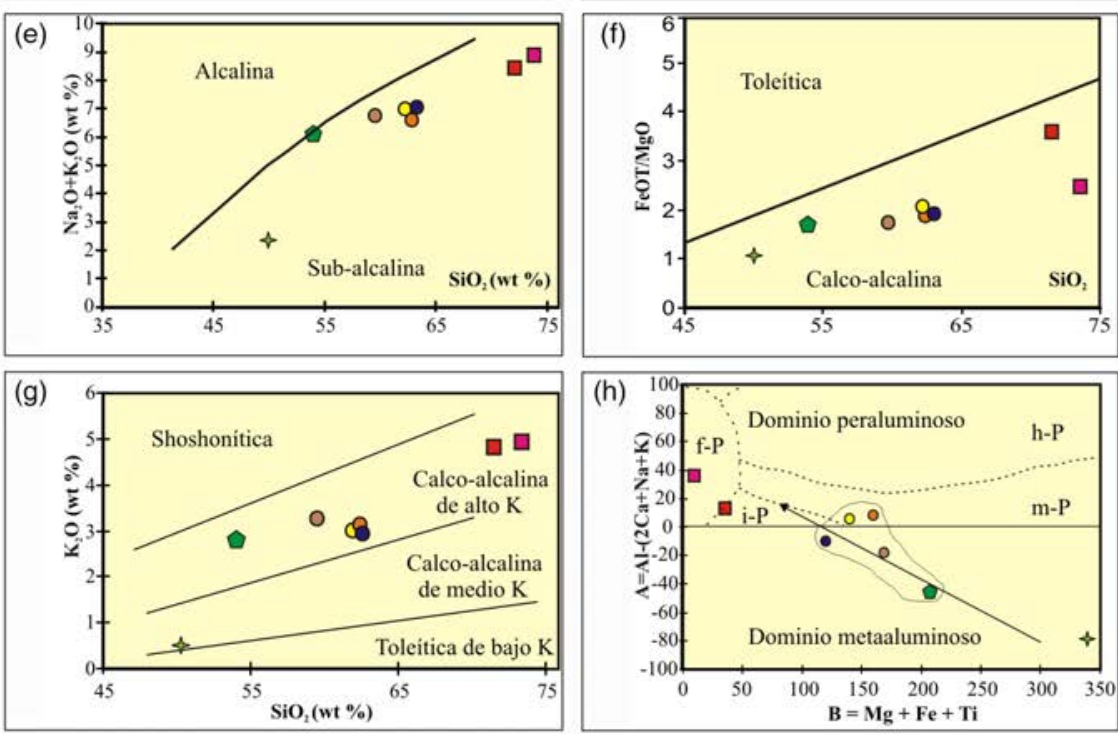

Fig. 6.-a) Diagrama de clasificación de rocas ígneas de de La Roche (1992) para las rocas de la Sierra de La Aguada. b; c; d) Diagrama de relación entre $\mathrm{FeO}_{\mathrm{t}} /\left(\mathrm{FeO}_{\mathrm{t}}+\mathrm{MgO}\right)$ vs $\mathrm{SiO}_{2} ; \mathrm{Al} /(\mathrm{Ca}-1.67 \mathrm{P}+\mathrm{Na}+\mathrm{K})$ vs $\mathrm{SiO}_{2}$ y $\mathrm{Na}_{2} \mathrm{O}+\mathrm{K}_{2} \mathrm{O}-\mathrm{CaO}$ vs $\mathrm{SiO}_{2}$ según Frost et al. (2001). e) Diagrama de Álcalis vs. Sílice Total (TAS) para rocas plutónicas, con la discriminación entre series de rocas alcalinas y subalcalinas según Irvine \& Baragar (1971). f) Diagrama $\mathrm{SiO}_{2}-\mathrm{FeO}_{\mathrm{t}} / \mathrm{MgO}$ de Miyashiro (1974). g) Diagrama $\mathrm{K}_{2} \mathrm{O}$ vs $\mathrm{SiO}_{2}$ para la subdivisión de la serie subalcalina según Peccerilo \& Taylor (1976). h) Diagrama A-B de Debon \& Le Fort (1983) modificado por Villaseca et al. (1998) para rocas ígneas. Las divisiones corresponde a: I-P: pobremente peraluminoso; m-P: moderadamente peraluminoso; h-P: altamente peraluminoso; f-P: peraluminoso félsico; metaluminoso: $A<0$.

un aspecto importante es el hecho de que las rocas se proyectan en diferentes campos del discriminante que usa la relación $\mathrm{Na}_{2} \mathrm{O}+\mathrm{K}_{2} \mathrm{O}-\mathrm{CaO}$ vs $\mathrm{SiO}_{2}$

(Fig. 6d). Por último, notoriamente se puede diferenciar dentro de las unidades ígneas analizadas dos grupos, uno correspondiente a rocas de característica 
geoquímicas intermedias-máficas calcoalcalinas y otro de rocas félsicas peraluminosas (Fig. 6).

\section{Elementos mayoritarios}

Unidad ígnea plutónica intermedia-máfica: el análisis de elemento mayoritarios indica que las rocas granodioríticas (muestras CW15; 17; 29; 32; ver Tabla 1) se caracterizan por presentar un carácter intermedio débilmente metaaluminoso a moderadamente peraluminoso, con contenidos de $\mathrm{SiO}_{2}$ entre $59 \%$ y $63 \%$ y un $16 \%$ de $\mathrm{Al}_{2} \mathrm{O}_{3}$ (Figs. $6 \mathrm{c}, 6 \mathrm{~h}$ y 7 ). En tanto que el enclave máfico (muestra CW30; ver Tabla 1) clasificado como monzogabro cuarzoso, se diferencia de las granodioritas al poseer menor contenido de $\mathrm{SiO}_{2}$ y $\mathrm{K}_{2} \mathrm{O}$, y mayor contenido en $\mathrm{Fe}_{2} \mathrm{O}_{3}{ }^{*}$, $\mathrm{TiO}_{2}, \mathrm{Al}_{2} \mathrm{O}_{3}, \mathrm{MgO}, \mathrm{CaO}, \mathrm{Na}_{2} \mathrm{O}$ y $\mathrm{P}_{2} \mathrm{O}_{5}$. Por último, el gabro (muestra CW24; ver Tabla 1) se caracteriza por un contenido en $\mathrm{SiO}_{2}$ cercano al $50 \%$ y de alúmina próximo al $18 \%$; con altas proporciones de hierro, magnesio y calcio, y bajos porcentuales de titanio, sodio, potasio y fósforo respecto de las granodioritas. En los diagramas Harker las rocas granodioríticas (Fig. 7), muestran una buena correlación para las variaciones de $\mathrm{TiO}_{2}, \mathrm{Fe}_{2} \mathrm{O}_{3}{ }^{*}, \mathrm{CaO}$ y $\mathrm{MgO}$ en función del $\mathrm{SiO}_{2}$, dada por la disminución en el contenido de estos óxidos con el incremento de la sílice (Fig. 7). Asimismo, si observamos comparativamente las variaciones de los óxidos mayoritarios entre el enclave de monzogabro y las granodioritas, estos muestran valores geoquímicos que indican un tren evolutivo que podría sugerir una relación cogenética. Asimismo, se destaca que las rocas granodioríticas pertenecen a la serie sub-alcalina (Fig. 6e) en el diagrama de sílice vs álcalis totales $\left(\mathrm{SiO}_{2} v s \mathrm{Na}_{2} \mathrm{O}\right.$ $+\mathrm{K}_{2} \mathrm{O}$ ) y por la relación $\mathrm{SiO}_{2} v s \mathrm{FeO}_{\mathrm{T}} / \mathrm{MgO}$ poseen características calcoalcalinas (Figs. 6e y 6f). En tanto que la muestra de enclave de monzogabro no permite establecer con certeza su carácter calcoalcalino o débilmente alcalino (Figs. 6e y 6f). No obstante, la relación de $\mathrm{SiO}_{2}$ vs $\mathrm{K}_{2} \mathrm{O}$ indica que el enclave máfico, al igual que las granodioritas poseen características de series calcoalcalinas con alto $\mathrm{K}_{2} \mathrm{O}$ (Figs. $6 \mathrm{~g}$ y $6 \mathrm{~h}$ ). Por su parte, el gabro muestran una afinidad no del todo precisa con series de rocas sub-alcalinas y calcoalcalinas (Figs. 6e y 6f), diferenciándose de las granodioritas al mostrar afinidad calcoalcalina de medio $\mathrm{K}_{2} \mathrm{O}$ (Figs. $6 \mathrm{~g}$ y $6 \mathrm{~h}$ ). Además, dicho gabro poseen menores contenidos de álcalis totales y de $\mathrm{TiO}_{2}$ y una relación $\mathrm{Fe}_{2} \mathrm{O}_{3} / \mathrm{MgO}<1,09$. El diagrama A-B de Debon \& Le Fort (1983) modificado por Villaseca et al. (1998) muestra, aunque no con absoluta claridad, que las granodioritas de la zona (Fig. 6h) presentan carácter metaluminoso a moderadamente peraluminoso, con índice A entre $-40 \mathrm{y}+10$, indicando un tren evolutivo parcialmente comparable con las series de rocas calcoalcalinas (Figs. 5f y $5 \mathrm{~h}$ ). Esto último expone probablemente, que estas rocas en su evolución han podido sufrir procesos de contaminación, que han ocasionado variaciones en su química global denotada en una baja correlación final en el mencionado diagrama. Esta propuesta es afianzada también por el hecho de contar con la presencia de numerosos xenolitos de metasedimentitas dentro de los cuerpos de granodioritas, los cuales están en ocasiones parcialmente asimilados, lo que indicaría una posible incorporación de roca de caja al magma y con ello una variación parcial en su química original.

Unidad ígnea plutónica félsica: los monzogranitos de la Sierra de La Aguada (muestras CW25; 26; ver Tabla 1), son félsicos y tienen altos contenidos en $\mathrm{SiO}_{2}$ el cual varía entre 71,5 \% y 73,5 \% (Figs. 6 y 7), siendo la abundancia de $\mathrm{SiO}_{2}$ aun mayor en los núcleos de los monzogranitos moscovíticos que yacen como diques aplopegmatíticos (Fig. 6e). En general, todos los granitos félsicos, presentan un carácter fuertemente peraluminoso (Figs. 6c y $6 \mathrm{~h}$ ), con contenidos en alúmina cercanos al $15 \%$ y bajos porcentajes de $\mathrm{TiO}_{2}, \mathrm{FeO}_{\mathrm{T}}, \mathrm{MgO}, \mathrm{CaO}$ y $\mathrm{Na}_{2} \mathrm{O}$ (Fig. 7). Asimismo, muestran un alto contenido en $\mathrm{K}_{2} \mathrm{O}$ siempre alrededor del $5 \%$ (Fig. 6g). Considerando solo los granitos que aparecen como diques aplopegmatíticos (monzogranito aplopegmatítico moscovítico), éstos presentan mayores contenidos de $\mathrm{SiO}_{2}, \mathrm{Al}_{2} \mathrm{O}_{3}, \mathrm{Na}_{2} \mathrm{O}$ y $\mathrm{K}_{2} \mathrm{O}$, mientras que se encuentran claramente empobrecidos en $\mathrm{TiO}_{2}, \mathrm{FeO}_{\mathrm{T}}, \mathrm{MgO}$ y $\mathrm{CaO}$ (Figs. 6 y 7). Todos los granitos félsicos se proyectan dentro del campo de los leucogranitos peraluminosos, definido por valores de $\mathrm{B}<38,8$ y de $\mathrm{A}$ entre 15 y 40 en el diagrama A-B de Debon \& Le Fort (1983; ver Fig. 6h). Según la propuesta de Villaseca et al. (1998) se trata de granitos fuertemente peraluminosos a peraluminosos félsicos (Fig. 6h). En particular la muestra correspondiente a los aplopegmatoides, presenta un carácter más peraluminoso y con menores valores de índice $\mathrm{B}$, lo que indica que son rocas 


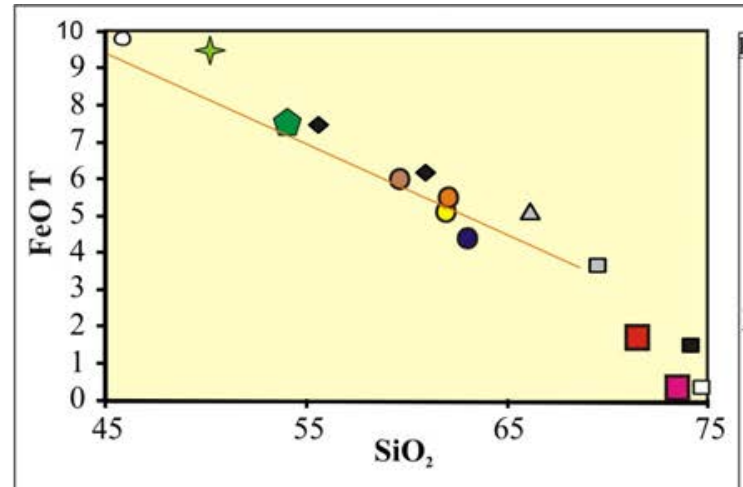

Rocas igneas Sierra de La Aguada

- CW 32 (Granodiorita hornblendifera biotitica)

CW 29 (Granodiorita hornblendifera biotitica)

CW 17 (Granodiorita hornblendifera biotitica)

- CW 15 (Granodiorita-tonalita biotitica)

$\square$ CW 25 (Monzogranito biotítico)

CW 26 (Monzogranito aplopegmatítico moscovítico)

- CW 30 (Enclave monzogabro hornbledifero biotitico)

$\nLeftarrow$ CW 24 (Gabro biotítico hornblendifero)

Rocas ígneas famatinianas Sierra Grande de San Luis (Morosini 2011

$\square$ Facies diques aplopegmatiticos La Escalerilla

Facies leucogranito La Escalerilla

$\square$ Facies granito La Escalerilla

Facies tonalitas

$\triangle$ Facies granodioritas

O Facies gabro/diorita
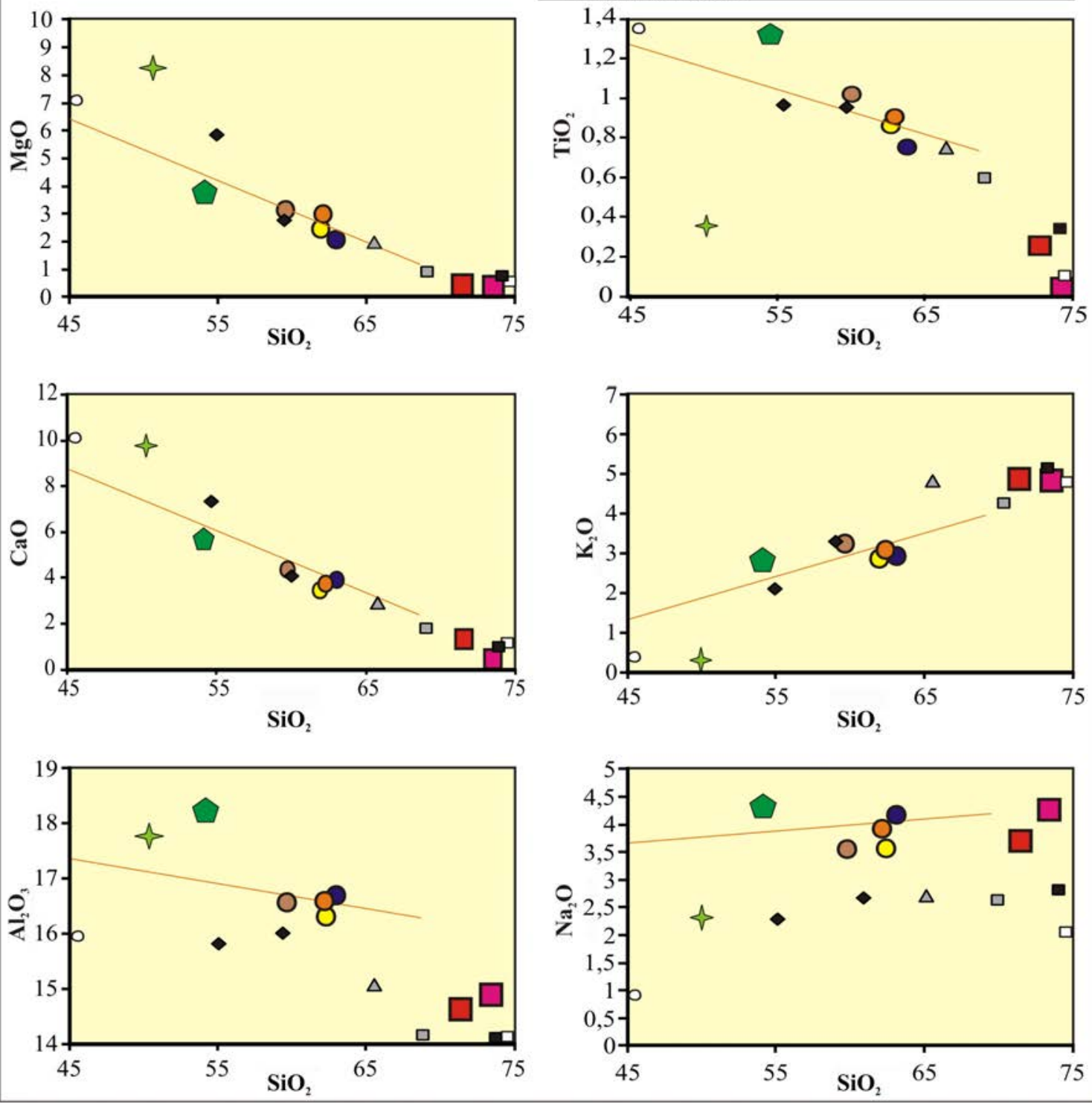

Fig. 7.-Diagramas binarios de variación (Harker) de óxidos mayoritarios $\mathrm{TiO}_{2}, \mathrm{CaO}, \mathrm{Al}_{2} \mathrm{O}_{3}, \mathrm{MgO}, \mathrm{P}_{2} \mathrm{O}_{5}, \mathrm{~K}_{2} \mathrm{O}, \mathrm{Na}_{2} \mathrm{O}$ y $\mathrm{Fe}_{2} \mathrm{O}_{3 \mathrm{t}}$ vs. $\mathrm{SiO} \mathrm{O}_{2}$ para rocas ígneas del complejo El Carrizal-La Aguada. Se proyectan también las muestras correspondientes a las rocas de la suite ordovícica de la Sierra Grande de San Luis tomadas de Morosini (2011) y Morosini et al. (2017). Se muestran las tendencias evolutivas a través de rectas, determinadas mediante regresiones lineales. 
más félsicas que los cuerpos ovoides. De acuerdo a las características geoquímicas presentadas en los diagramas Harker (Fig. 7) y en particular en el diagrama de Debon \& Le Fort (1983; Fig. 6h) para los granitoides peraluminosos, se muestra que sin distinción de yacencia estas rocas responden a la serie de rocas aluminosas.

\section{Elementos trazas}

Unidad ígnea plutónica intermedia-máfica: las rocas granodioríticas presentan altos contenidos de $\mathrm{Cs}, \mathrm{Rb}$, anomalías positivas en $\mathrm{Ba}, \mathrm{K}, \mathrm{Sm}$ y $\mathrm{Pb}$ y bajas concentraciones de elementos de alto potencial iónico (HFSE) tales como Th, Nb, Sr, Zr, Ti e $\mathrm{Y}$, cuando se los proyecta en un diagrama de multielementos normalizado a manto primitivo (Fig. 8). Los altos contenidos en elementos litófilos (LILEs) observados en estas litologías, se pueden explicar por la presencia de fases minerales compatibles con estos elementos, tal es el caso de la biotita para $\mathrm{Cs}, \mathrm{Rb}$ y $\mathrm{Ba}$ y el feldespato potásico para $\mathrm{Ba}$. El enclave máfico (monzogabro), presentan un patrón de multielementos similar al de las granodioritas (Fig. 8), con concentraciones absolutas similares de elementos traza. Una diferencia remarcable, es que el enclave de monzogabro muestra una anomalía negativa más importante en Th y menores concentraciones de Cs y Rb. Asimismo, el gabro de la Sierra de La Aguada muestra siempre respecto de las granodioritas, un empobrecimiento marcado en elementos traza, en general, y en elementos incompatibles, en particular (Fig. 8). También exhibe concentraciones equivalentes de $\mathrm{Zr}$ e $\mathrm{Y}$, similares anomalías positivas en $\mathrm{Ba}$ y $\mathrm{Sm}$, anomalías negativas en $\mathrm{Th}, \mathrm{Nb}$, $\mathrm{Ti}$ y $\mathrm{Rb}$ y alto contenido de $\mathrm{Sr}$ (a excepción de una muestra), siendo esto coherente con la ausencia de feldespato potásico y la abundante plagioclasa. Por su parte, si se analiza el patrón de tierras raras (REE; ver Fig. 8) las granodioritas muestran una anomalía levemente negativa en $\mathrm{Eu}$ (entre 0,93 y 0,78), y poseen un patrón con pendiente variable de moderada a alta, con valores de relación $(\mathrm{La} / \mathrm{Yb})_{\mathrm{N}}$ entre 8 y 66. Dicho patrón indica que las granodioritas exponen mayores contenidos en tierras raras ligeras (LREE) respecto de las tierras raras pesadas (HREE). No obstante, si bien todas presentan menores contenidos de HREE en relación a LREE, hay que remarcar que la concentración de HREE no es igual entre los distintos tipos de granodioritas analizadas, encontrándose algunas más empobrecidas que otras (Fig. 8). El enclave máfico monzogabro muestran un patrón de variación indistinguible del que poseen las rocas granodioríticas (Fig. 8). En general exhibe una anomalía levemente negativa de $\mathrm{Eu}\left(\mathrm{Eu} / \mathrm{Eu}^{*} 0,82\right.$ donde $\mathrm{Eu}^{*}$ es 24,6$)$ y relaciones $(\mathrm{La} / \mathrm{Yb})_{\mathrm{N}}$ de $29,17$. Además, se presenta enriquecido en LREE y empobrecido en HREE (Fig. 8). Por último el gabro está empobrecido en LREE y MREE 100 veces respecto de las granodioritas y el enclave máfico, mientras que su concentración de HREE es similar a dichas rocas (Fig. 8). También presenta una relación (La/ $\mathrm{Yb})_{\mathrm{N}}$ de 1,49 , sugiriendo que el fraccionamiento de LREE respecto de HREE es mínimo, mientras que la anomalía positiva en $\mathrm{Eu}\left(\mathrm{Eu} / \mathrm{Eu}^{*}=1,8\right)$ se debe a la fraccionación y acumulación de plagioclasa.

Unidad ígnea plutónica félsica: los monzogranitos biotíticos se caracterizan por una gran abundancia en LILEs ( $\mathrm{Rb}, \mathrm{Sr}, \mathrm{Ba}$ ), con altas concentraciones en $\mathrm{Zr}$, a la vez que presentan anomalías negativas en $\mathrm{Nb}$, P, Ti e Y (Fig. 8). La abundancia en los elementos litófilos, puede relacionarse con la presencia de fases minerales como biotita, en donde $\mathrm{Cs}$ y $\mathrm{Rb}$ son compatibles, como así también microclino y ortoclasa para $\mathrm{Ba}$, mientras que los altos contenidos en $\mathrm{Zr}$ se relacionan con la presencia de circón. Por otra parte, las anomalías negativas en $\mathrm{Nb}$, Ti, Sr e Y pueden asociarse con la permanencia como fases estables de ilmenita, plagioclasa y granate en la fuente de los magmas graníticos (Fig. 8). Cabe destacar, que los núcleos aplíticos de los diques de monzogranitos aplopegmatíticos moscovíticos, se diferencian marcadamente de las demás litologías representadas en el diagrama multielemental (Fig. 8). Las aplitas muestran un empobrecimiento marcado en casi todos los elementos traza, excepto en $\mathrm{Cs}, \mathrm{Rb}, \mathrm{Nb}$ y $\mathrm{P}$ que se hallan enriquecidos respecto de los monzogranitos biotíticos. Además, estas rocas presentan altos contenidos en elementos incompatibles como $\mathrm{Cs}, \mathrm{Rb}, \mathrm{Nb}$ y Li, elementos que comúnmente forman fases minerales estables en pegmatoides derivados de líquidos magmáticos residuales. El patrón de tierras raras (Fig. 8) de los monzogranitos biotíticos se caracterizan por una moderada pendiente, con una relación $\mathrm{La}_{\mathrm{N}} / \mathrm{Yb}_{\mathrm{N}}=40,86$ y una anomalía negativa 

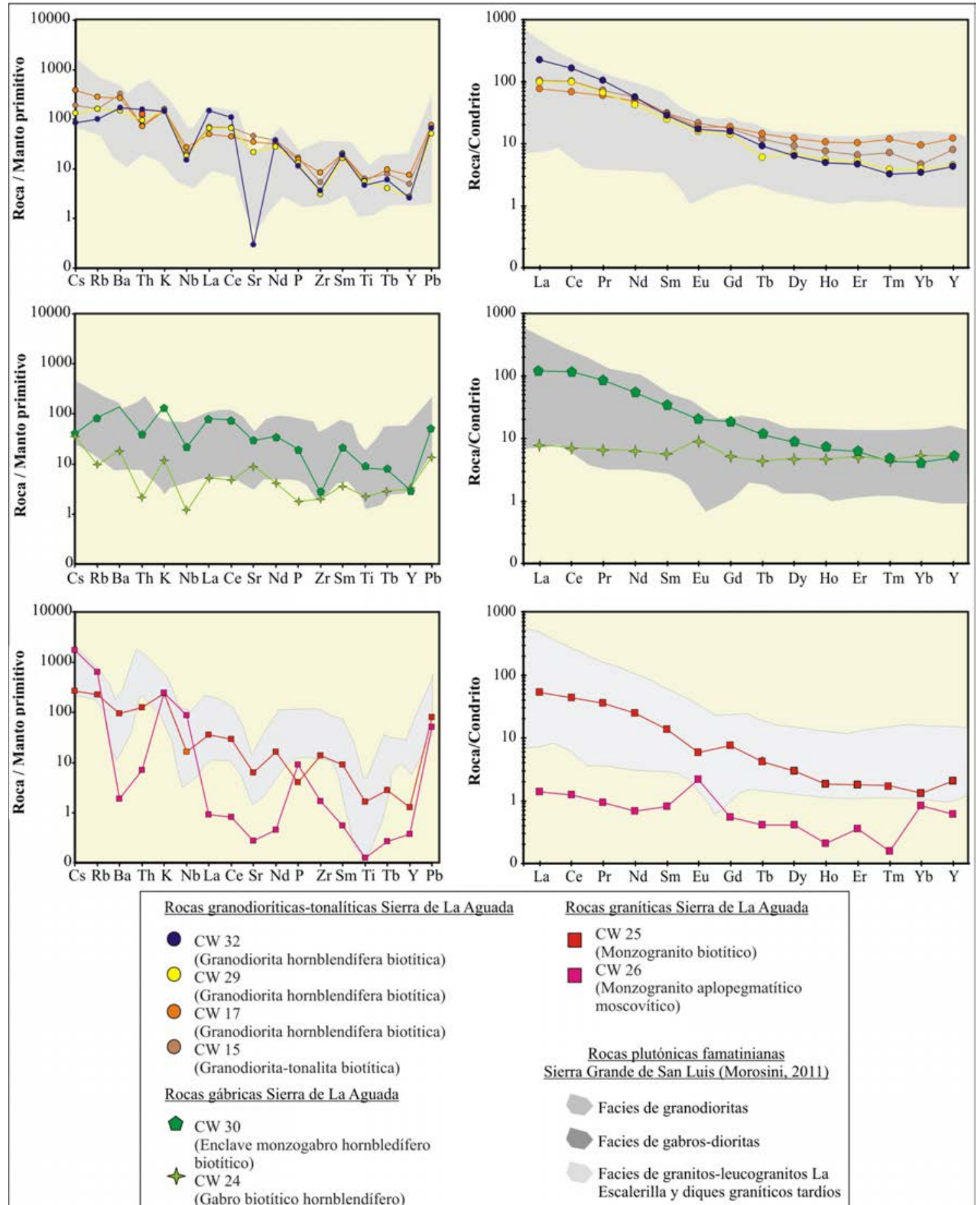

Rocas graníticas Sierra de La Aguada

$\mathrm{CW} 25$

(Monzogranito biotitico)

CW 26

(Monzogranito aplopegmatítico moscovitico)

Rocas plutónicas famatinianas Sierra Grande de San Luis (Morosini, 2011)

Rocas gábricas Sierra de La Aguada

Facies de granodioritas

Facies de gabros-dioritas

Facies de granitos-leucogranitos La Escalerilla y diques graniticos tardios

Fig. 8.—Diagramas "Spider" o Multielementales normalizados a manto primitivo y diagramas de Elementos de Tierras Raras (REE) normalizados a condrito (Taylor \& McLennan, 1985) para las rocas del complejo El Carrizal-La Aguada. Se presentan las muestras de la Sierra de La Aguada y como área sombreada las muestras de la suite ordovícica Famatiniana de la Sierra Grande de San Luis tomadas de Morosini (2011) y Morosini et al. (2017).

en $\mathrm{Eu}\left(\mathrm{Eu} / \mathrm{Eu}^{*} \sim 0,6\right)$, explicada por retención de este elemento en la fuente o por cristalización fraccionada de plagioclasa. Además, muestran un menor fraccionamiento dentro del grupo LREE respecto del grupo HREE con una relación $\mathrm{La}_{\mathrm{N}} / \mathrm{Sm}_{\mathrm{N}}=3,9 \mathrm{y}$ relaciones $\mathrm{Gd}_{\mathrm{N}} / \mathrm{Yb}_{\mathrm{N}}=5,75$. Por su parte los diques 
aplopegmatíticos de monzogranitos moscovíticos, presentan un patrón de variación disímil respecto de los monzogranitos biotíticos (Fig. 8). Estos tienen concentraciones notoriamente menores de REE y menor fraccionamiento de REE para esta litología, manifestado en la relación $\mathrm{La}_{\mathrm{N}} / \mathrm{Yb}_{\mathrm{N}}=1,64$, con un patrón de REE moderadamente plano y con fuerte anomalía positiva de Eu. Los bajos contenidos en REE de estos diques aplopegmatíticos pueden ser coherentes si se considera a éstas rocas como productos de fundidos anatécticos corticales (tipo-S) diferenciados, siendo análogo con lo deducido en el comportamiento de otros elementos traza.

\section{Discusión}

\section{Consideraciones generales del complejo El Carrizal-La Aguada}

La Sierra de La Aguada muestra una historia geológica diversa y extensa, en cuanto al desarrollo de eventos de deformación, metamórficos e ígneos, y las características intrínsecas de cada uno de estos. Dicha diversidad geológica ha llevado a definir en ella la presencia de un complejo ígneo-metamórfico denominado El Carrizal-La Aguada, conformado por tres unidades lito-estratigráficas (metasedimentaria, ígnea plutónica intermedia y máfica, e ígnea plutónica félsica), claramente diferenciadas por características de yacencia, petrología y geoquímica.

Las rocas de la unidad metasedimentarias, registran un evento metamórfico dinamo-térmico regional principal, acaecido en condiciones de facies de anfibolita de bajo a medio grado, inferidas por las asociaciones paragenéticas dominadas por Qtz-Pl-

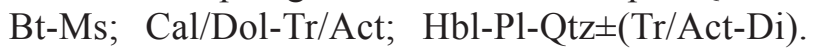
De acuerdo a los tipos litológicos reconocidos y sus asociaciones paragenéticas, los protolitos de dichas rocas corresponderían a grauvacas, pelitas, e intercalaciones menores de calizas, los cuales se podría asociar a un ambiente de sedimentación vinculado a un margen continental, aunque esto es aún un tema muy controversial en la geológica regional (ver Sims et al., 1997; von Gosen \& Prozzi, 1998; Steenken et al., $2010 \mathrm{y}$ citas en éste). Considerando las características observadas entre el metamorfismo y la deformación, las rocas metasedimentarias de la Sierra de La Aguada, se podrían correlacionar con las rocas que componen gran parte del borde oriental de la Sierra de San Luis, y que han sido agrupadas dentro del Complejo Metamórfico Conlara (ver Ortiz Suárez, 1988; Ortiz Suárez et al., 2009; von Gosen \& Prozzi, 1998; Azcurra, 2001; Whitmeyer \& Simpson, 2004; Siegesmund et al., 2010; Fig. 1), o bien ser en parte equivalentes a las rocas que conforman el denominado "Complejo Las Aguadas" definido por Ortiz Suárez (1988) y ubicado al noroeste de la localidad de Concarán (ver Fig. 1), cuyo grado metamórfico rara vez alcanza a desarrollar una importante anatexis de los protolitos sedimentarios. De acuerdo a esto, los protolitos de las metamorfitas aquí estudiadas, tendrían una edad comprendida entre el Neoproterozoico al Cámbrico inferior, y el evento deformacional-metamórfico que registran habría sucedido con posterioridad al Cámbrico inferior (ver Whitmeyer \& Simpson, 2004; Ortiz Suárez et al., 2009).

Las rocas ígneas agrupadas dentro de la unidad plutónica intermedia y máfica, son dominantemente granodioritas hornblendífero-biotíticas. Estas granodioritas poseen relaciones de campo intrusivas con las granodioritas-tonalitas biotíticas y están espacialmente relacionada con las rocas gábricas. Asimismo, todo el conjunto de rocas ígneas intruye a la unidad metasedimentaria y las relaciones de campo indican que la intrusión plutónica ocurrió de manera previa al evento deformacional milonítico (cizallamiento dúctil-frágil) que afectan a todo el conjunto litológico. Si bien la temporalidad de dicha fase no está acotada con certeza, tomando hipotéticamente a la serranía como parte del Complejo Metamórfico Conlara (Fig. 1), se interpreta que el desarrollo de dichas fajas de cizalla se correlaciona con la fase compresiva final ligada al cierre del orógeno Famatiniano (Ortiz Suárez et al., 2009; Sims et al., 1997; Steenken et al., 2010).

Las rocas granodioríticas y gábricas presentan un carácter geoquímico calcoalcalino y relaciones de elementos mayoritarios y trazas parcialmente similares a rocas ligadas a ambientes de arco magmático (Figs. 6, 7, 8 y 9). Tanto las granodioritas como gabros se pueden agrupar dentro de los granitoides magnesianos, lo cual descarta la posibilidad de un origen anorogénico típico de granitoides tipo-A (Frost et al., 2001). Además, si evaluamos el 

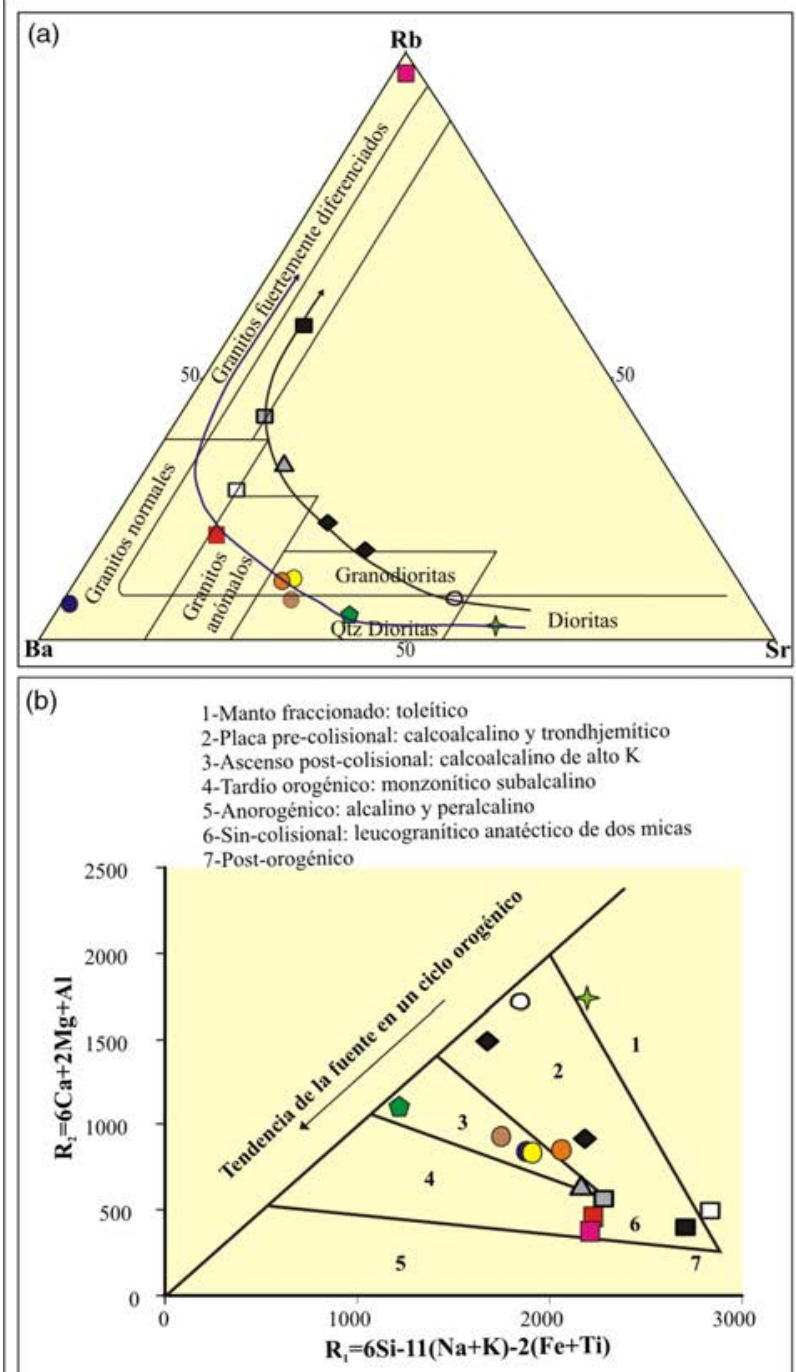

Rocas igneas Sierra de La Aguada

- $\mathrm{CW} 32$

(Granodiorita hornblendifera biotítica)

O $\quad$ CW 29

(Granodiorita hornblendifera biotítica)

- $\mathrm{CW} 17$

(Granodiorita hornblendifera biotitica)

CW 15

(Granodiorita-tonalita biotitica)

CW 25

(Monzogranito biotítico)

CW 26

(Monzogranito aplopegmatítico

moscovitico)

- $\mathrm{CW} 30$

(Enclave monzogabro hornbledifero biotitico)

$\nLeftarrow$ CW 24

(Gabro biotitico hornblendifero)

Rocas igneas famatinianas Sierra

Grande de San Luis (Morosini 2011)

$\square$ Facies diques aplopegmatiticos La Escalerilla

- Facies leucogranito La Escalerilla

$\square$ Facies granito La Escalerilla

Facies tonalitas

$\triangle$ Facies granodioritas

○ Facies gabro/diorita

Tendencia evolutiva de las rocas igneas $\longrightarrow$ Sierra de La Aguada

Sierra Grande de San Luis
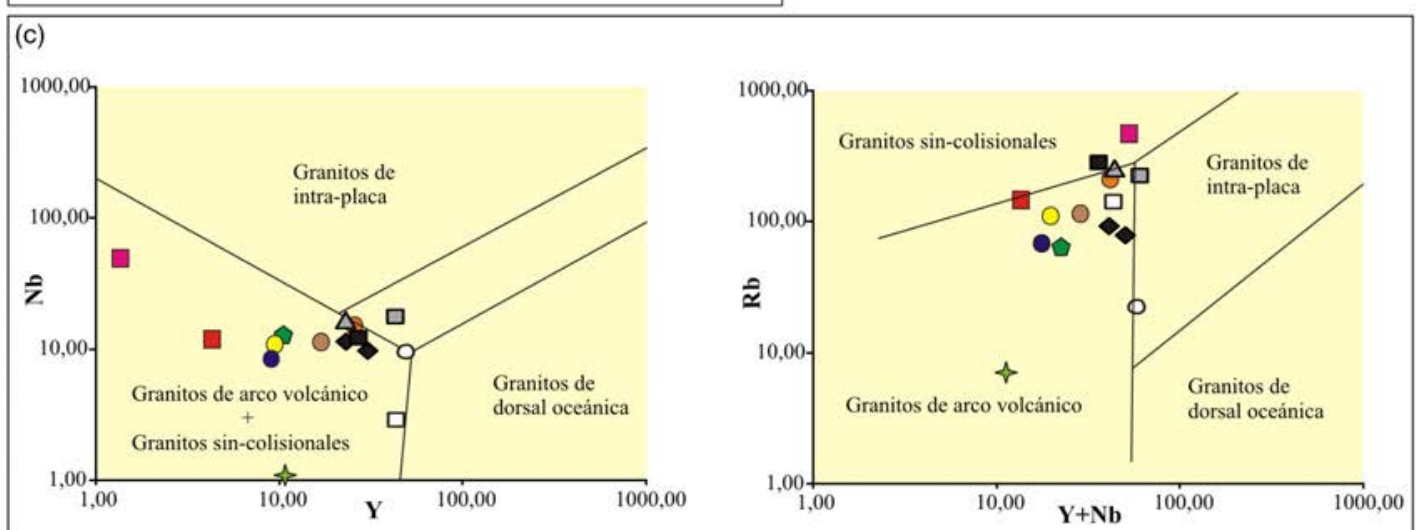

Fig. 9.-a) Diagrama triangular de diferenciación en base a los elementos trazas (Rb-Sr-Ba) según El Bouseily \& Sokkary (1975). Se presentan las líneas de tendencia evolutiva para las diferentes series de rocas. b) Diagrama de clasificación tectono-magmática de Batchelor \& Bowden (1985). c) Diagramas de clasificación de ambientes tectónicos, en base a las relaciones de los elementos traza $\mathrm{Rb}, \mathrm{Nb}$ e $\mathrm{Y}$ basados en Pearce et al. (1984). En las figuras a, b y c se proyectan las muestras correspondientes a las rocas ígneas de la Sierra de La Aguada y las de la suite ordovícica de la Sierra Grande de San Luis tomadas de Morosini (2011) y Morosini et al. (2017). 
ambiente tectónico de origen en base a los diagramas de discriminación tectónica de Pearce et al. (1984), tanto las granodioritas como el gabro corresponderían a intrusivos ligado a un arco volcánico, por lo cual se refuerza dicha génesis (Fig. 9c). Del mismo modo si analizamos la discriminación geoquímica propuesta por Batchelor \& Bowden (1985), las granodioritas y el enclave máfico derivarían de magmas calcoalcalinos de alto $\mathrm{K}_{2} \mathrm{O}$ de ascenso poscolisional, lo cual no es consistente totalmente con las relaciones de campo observada en torno a la deformación que afecta a las rocas, en tanto que el gabro se vincula a un manto fraccionado toleítico (Fig. 9b). Más allá de las discrepancias entre las clasificaciones tectónicas, las cuales en muchos casos no son absolutamente certeras, si tomamos en cuenta que tanto las granodioritas como el gabro muestran características geoquímicas variadas en cuanto a exceso de alúmina e índice de calcio, esto induce a evaluar la fuerte posibilidad en su génesis de la existencia de más de un proceso de diferenciación, y que tal vez puedan ser derivadas de más de un tipo de roca fuente (Kelemen et al., 2003). En relación a esto, una posibilidad es que el gabro pueda derivar de la cristalización fraccionada de magmas primarios típicamente de ambientes de arco. En tanto que las granodioritas, tendrían una génesis más compleja y se podrían ligar en el mismo contexto geodinámico, a procesos de mezcla y contaminación de los magmas. Esto último, se vislumbra en las variaciones de su química global, que indicarían un posible enlace con procesos de contaminación con el encajante metamórfico. Dicha hipótesis ya ha sido indicada para la génesis de rocas similares del arco Famatiniano en varios sectores de las Sierras Pampeanas (ver Otamendi et al., 2012; Bellos et al., 2015; Alasino et al., 2016 y citas en estos) y podría ser una de las propuestas más fiable para el origen de las rocas aquí estudiadas.

Las rocas de la unidad plutónica félsica, varían desde cuerpo decamétricos ovoides globosos de monzogranitos biotíticos hasta diques aplopegmatíticos de monzograníticos moscovíticos. Los monzogranitos biotíticos son fuertemente peraluminosos y posiblemente sean el producto de procesos de anatexis cortical, cuyos fundidos se han emplazados en relación para-autóctona con la secuencia metasedimentaria e ígnea regional (Figs. 6, 7, 8 y 9). Por su parte los diques aplopegmatíticos tienen afinidad geoquímica y rasgos petrográficos que sugieren un origen también relacionado a procesos de anatexis, siendo estos semejantes a los fundidos peraluminosos derivados de la fusión parcial cortical, y cuya génesis es coherente dado su vinculo petrogenético al resto de las rocas ígneas y al ambiente en el cual se han generado (Figs. 6, 7, 8 y 9). Por otra parte, si evaluamos el ambiente tectónico de origen en base al diagrama de Batchelor \& Bowden (1985), todos los granitoides mencionados derivarían de fundidos de origen sin-colisional, y se correlacionan con leucogranitos anatécticos de dos micas, afianzando la propuesta sobre su origen. En tanto que evaluando los diagramas de Pearce et al. (1984), las rocas se posicionan en el campo de granitos sin-colisionales de arco volcánico (Figs. 9b y 9c).

Finalmente, es de destacar que la secuencia litológica actualmente expuesta en la Sierra de La Aguada, demuestra en sus asociaciones minerales, texturas, estructuras y relaciones de intrusividad, que nunca fue soterrada a profundidades importantes como para producir un gradiente metamórfico superior a la parte baja de la facies de anfibolita. De igual manera no se observa anatexis in-situ, por lo cual el magmatismo peraluminoso anatéctico presente en la serranía y cuyo origen indica proceso de fusión parcial, tendría un carácter alóctono.

\section{Correlación entre el magmatismo de la Sierra de La Aguada y el arco Famatiniano}

La presencia en todo el ámbito de Sierras Pampeanas, y en este caso en particular en serranías del este de San Luis, de numerosos dominios de rocas plutónicas calcoalcalinas las cuales exhiben afinidad genética y temporal (Figs. 1 y 10 ), sugiere que en el contexto geodinámico acontecido en el borde oriental de Gondwana entre los 490 Ma y 465 Ma se desarrolló un magmatismo de arco generalizado (Pankhurst et al., 1998, Sato et al., 2003, Morosini et al., 2009, Steenken et al., 2010; Morosini et al., 2017 y citas en éste). Dicho magmatismo a escala regional se lo enmarca dentro del contexto del arco Famatiniano, cuya máxima expresión litológica (rocas plutónicas-volcánicas) se encuentra actualmente expuesta en las serranías de Valle Fértil-La Huerta, Ulapes-Chepes y el cordón del Famatina (Figs. 1 y 10), aunque se expone 


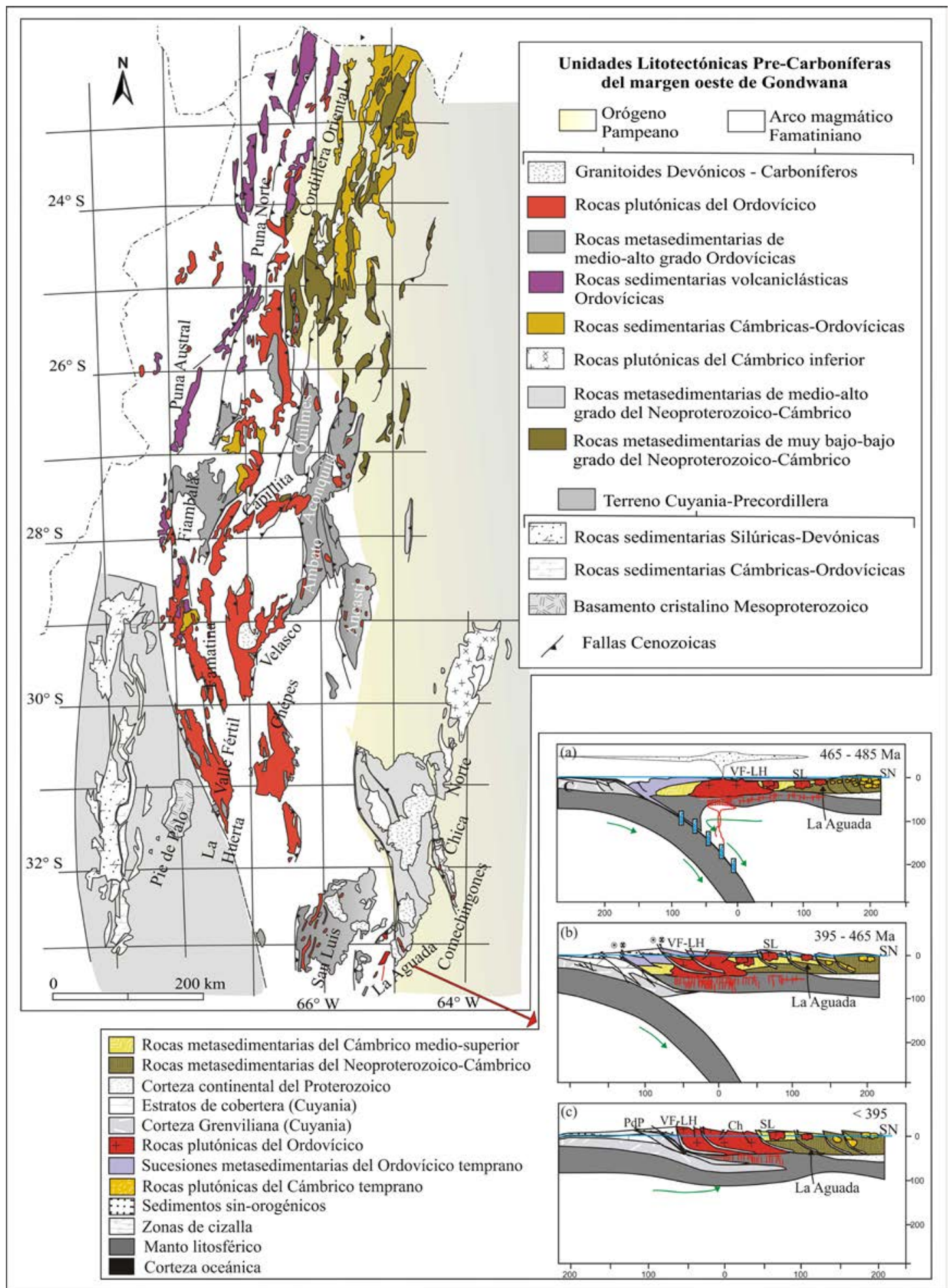

Fig. 10.-Mapa de las principales unidades litoestratigráficas del Neoproterozoico-Paleozoico del centro y noroeste de Argentina. Se destaca la distribución de las secuencias plutónicas-volcánicas del arco magmático Famatiniano. También se expone una sección transversal esquemática E-O que exhibe la evolución del arco Famatiniano en su segmento central (modificada de Cristofolini et al., 2012). Se indican los principales cordones serranos y la posición de la Sierra de La Aguada, aquí estudiada. PdP (Pie de Palo); VF-LH (Valle Fértil-La Huerta); Ch (Chepes); SL (San Luis); SN (Sierra Norte de Córdoba). 
de manera generalizada a lo largo de todo el país, desde la Puna en la provincia de Jujuy hasta la provincia de la Pampa (ver Pankhurst et al., 1998, Coira et al., 2009; Chernicoff et al., 2010; Ducea et al., 2010; Grosse et al., 2011; Cristofolini et al., 2012; Otamendi et al., 2012). Basados en el mencionado contexto geológico y dada la existencia de rocas plutónicas afines a un magmatismo calcoalcalino expuesto en la serranía de La Aguada, la zona estudiada hipotéticamente podría ser parte de un sistema de arco magmático, vinculado a escala regional con el orógeno Famatiniano (Figs. 1 y 10). La ausencia de dataciones absolutas en la zona de estudio no permite confirmar su vínculo, a pesar de ello, y teniendo en cuenta la similitud geoquímica de las litologías analizadas con aquellas vinculadas a través de dataciones isotópicas al arco Famatiniano expuesto en la Sierra Grande de San Luis (Morosini, 2011; Morosini et al., 2017; Figs. 1 y 10), se puede apoyar su probable correlación genética-temporal. Esto último afianzado también en el hecho de que tanto en la Sierra Grande de San Luis como en La Aguada, las rocas plutónicas son afectadas por fajas de cizalla localizadas, las cuales se vincularían a la fase final de la orogenia Famatiniana, posiblemente asociadas al estadío colisional del terreno Cuyania/ Precordillera sobre el proto-margen de Gondwana (Ordovícico superior-Silúrico; ver Sato et al., 2003, Steenken et al., 2010; Cristofolini et al., 2014). Por lo tanto, la edad del magmatismo estudiado en este trabajo, es por lo menos anterior a dichas zonas de cizalla e indica que las rocas plutónicas de ambas serranías podrían tener una relación temporal afín.

Las granodioritas, gabros y granitoides félsicos de La Aguada fueron proyectados en los diagramas binarios Harker (Figs. 6), comparativamente junto a un conjunto rocas similares de la suite ordovícica Famatiniana presentes en las Sierra Grande de San Luis (Morosini, 2011; Morosini et al., 2017; Figs. 1, 2 y 10). En estos diagramas se muestra que los trends evolutivos de las rocas de ambas serranías son similares, donde los óxidos mayoritarios exponen un patrón de variación respecto a $\mathrm{SiO}_{2}$ semejante, indicando un posible vínculo petrogenético.

De la misma forma, las rocas granodioríticas de La Aguada fueron proyectadas también en el diagrama "Spider" normalizado a manto primitivo, comparativamente a granodioritas de la suite ordovícica
Famatiniana (Morosini, 2011; Morosini et al., 2017). En este diagrama se observa una correlación clara de los contenidos de elementos trazas entre las rocas (Figs. 8 y 10). Se aprecia que ambos grupos de granodioritas presentan altos contenidos en LILEs y bajas concentraciones de HFSE (Fig. 8). También se observan coincidencias en las anomalías levemente negativa en $\mathrm{Eu}$, y exhiben un patrón común en REE, de pendiente moderada, con mayores contenidos en LREE, menores de HREE y abundancia en MREE (Fig. 8). De esta manera se puede ver que la caracterización de elementos trazas de ambas series de granodioritas, son coincidentes, afianzando el posible vinculo de una génesis común.

Asimismo, si comparamos las rocas gábricas s.l. de ambas serranías, estas muestran un patrón de elementos trazas parcialmente coincidentes con contenidos en LILEs ( $\mathrm{Cs}, \mathrm{Rb}, \mathrm{Ba}$ ) moderados a altos y bajas concentraciones de HFS (Nb, Th, Zr, Y, Ti). Aunque, el gabro de la Sierra de La Aguada, está más deprimido en general en LILEs y HFS, escapando de la media de concentraciones de las rocas gábricas Famatinianas (Fig. 8). Por su parte el enclave máfico de La Aguada, muestra concentraciones de LILEs y HFS similares a los gabros de San Luis. En tanto que el patrón de REE del gabro de La Aguada expone algunas variaciones. En general el fraccionamiento de LREE respecto de HREE es mínimo en el gabro de La Aguada, en tanto que es marcado en los gabros Famatinianos, con mayores contenidos en LREE y menores de HREE (Fig. 8). Una diferencia sustancial es la anomalía de $\mathrm{Eu}$, que es positiva $\left(\mathrm{Eu} / \mathrm{Eu}^{*}=1,8\right)$ en el gabro de La Aguada mientras que en negativa para los gabros de la Sierra Grande de San Luis. Por su parte el enclave máfico de La Aguada, muestra un patrón de REE similar a los gabros Famatinianos. Consecuentemente, aunque las características petrológicas y las relaciones de campo indican que el contexto regional en el cual se habrían generado tanto las rocas plutónicas de La Aguada como las de las Sierras Grande de San Luis, se podrían vincular como parte del mismo arco magmático, las correlaciones geoquímicas no son totalmente contundentes para aseverarlo sin discrepancia alguna, solo pudiendo sortear tal inconveniente con la incorporación a futuro de datos isotópicos que hagan aún más fuerte el análisis planteado. 
Por último, si se compara los patrones de elementos trazas de las rocas peraluminosas de La Aguada con rocas graníticas de la suite ordovícica Famatiniana de San Luis, se observa una semejanza parcial. Los cuerpos de monzogranitos biotíticos presentan una marcada semejanza a las rocas graníticas Famatinianas, con una abundancia en LILEs y moderada a bajas concentraciones de HFS, exhibiendo anomalías negativas en $\mathrm{Nb}, \mathrm{Sr}$, P, Ti e Y (Fig. 8). En cuanto al patrón de REE los monzogranitos biotíticos también se asemejan a las granitoides Famatinianos, por mostrar en consonancia una moderada pendiente $\left(\mathrm{La}_{\mathrm{N}} / \mathrm{Yb}_{\mathrm{N}}=40,86\right)$, una anomalía negativa en Eu y un menor fraccionamiento de LREE respecto de HREE (Fig. 8). Teniendo siempre en cuenta que a nivel mundial las relaciones geoquímicas de rocas anatécticas peraluminosas son similares, en este caso en particular si vinculamos el contexto geológico regional donde se hallan inmersas las rocas analizadas, podríamos pensar que las mismas pueden tener un nexo genético común dentro del contexto del magmatismo ordovícico. Por su parte, los diques de monzogranitos aplopegmatíticos moscovíticos de La Aguada, se diferencian marcadamente de las rocas graníticas de la Sierra Grande de San Luis, mostrando patrones de elementos trazas disímiles. En general están empobrecidos en todos los elementos traza con respecto a las rocas de la suite ordovícica Famatiniana, excepto en $\mathrm{Cs}, \mathrm{Rb}, \mathrm{Nb}, \mathrm{P}, \mathrm{y} \mathrm{Pb}$ que se hallan enriquecidos en ambas litologías. En tanto que los patrones de REE son muy diferentes, los diques de monzogranitos aplopegmatíticos exhiben concentraciones notoriamente menores de REE con un patrón casi plano, denotando un menor fraccionamiento de REE comparativamente con las rocas Famatinianas. Además, todo el patrón de REE cae fuera de las concentraciones medias de las rocas Famatinianas (Fig. 8). Por lo tanto estas rocas no presentan en sus rasgos geoquímicos un patrón tan claro que puede afirmar su vínculo genético. Aunque cabe destacar, que teniendo en cuenta el contexto geológico, los diques peraluminosos estudiados pueden en tal caso ser correlacionados con el evento pegmatítico que domina las Sierras del Portezuelo y La Estanzuela muy próximas al área aquí analizada, y congregadas dentro del grupo de pegmatitas clase moscovítica ligadas a etapas tardía del magmatismo Famatiniano, tal como lo demuestra Galliski (1994), las cuales muestran características geoquímicas afines a un origen anatéctico semejantes a las rocas estudiada en este trabajo.

Finalmente, si evaluamos además comparativamente el ambiente tectónico de origen de las rocas granodioríticas y gábricas de La Aguada con respecto a las de la suite Famatiniana de la Sierra Grande de San Luis mediante la discriminación geoquímica de Batchelor \& Bowden (1985), vemos una coincidencia entre ella (Figs. 9b y 9c). Las granodioritas de ambas serranías se proyectan en el campo de magmas calcoalcalinos de alto $\mathrm{K}_{2} \mathrm{O}$ derivados de ascenso poscolisional, aunque las relaciones de campo, geoquímica y edades radiométricas ajustan su origen a un ambiente de arco magmático. En tanto que el gabro de La Aguada se vincula a un manto fraccionado toleítico, mientras que para los del oeste de la Sierra Grande de San Luis derivan de una placa pre-colisional calcoalcalina-trondhjemítica. Por su parte, mediante el diagramas de discriminación tectónica de Pearce et al. (1984), las granodioritas y gabros de ambas serranías corresponderían a intrusivos ligados a un arco volcánico, pudiendo inducir su vínculo genético (Fig. 9c). Asimismo, si comparamos el ambiente tectónico de los granitoides peraluminosos de ambas serranías, todos derivarían de fundidos de origen sin-colisional (leucogranitos anatécticos de dos micas), en tanto que según los diagramas de Pearce et al. (1984) se proyectan en el campo de granitos sin-colisionales de arco volcánico, pudiendo indicar una génesis parcialmente común (Figs. 9b y 9c).

\section{Conclusiones}

La Sierra de La Aguada expone un basamento dominado por rocas plutónicas intermedias-máficas de afinidad calcoalcalina y subordinadamente granitoides félsicos peraluminosos, todas intruidas en metamorfitas de bajo a medio grado metamórfico. Como resultado del análisis de las relaciones de campo, la petrografía y las comparaciones geoquímicas se puede promover, de manera no absoluta, que el conjunto de rocas plutónicas presentes se relaciona al desarrollo de un arco magmático, cuya correlación regional lo vincularía al arco Famatiniano. 


\section{AGRADECIMIENTOS}

Este trabajo fue subsidiado por los proyectos PICT 00453/10 y PICT 0572/13 de la Agencia Nacional de Promoción Científica y Tecnológica Argentina y a través del fondo de ayuda de la Secretaria de Ciencia y Técnica de la Universidad Nacional de Río Cuarto, Argentina. Agradecemos las valiosas y acertadas sugerencias y correcciones realizadas por los revisores anónimos, ya que las mismas han sido sustanciales para mejorar la calidad final del trabajo, así como también la excelente guía del editor de la revista Jose María Cebria.

\section{Referencias}

Aceñolaza, F.G. \& Toselli, A.J. (1976). Consideraciones estratigráficas y tectónicas sobre el Paleozoico inferior del Noroeste Argentino. Actas del $2^{\circ}$ Congreso Latinoamericano de Geología, Caracas, 2: 755-763.

Alasino, P.H.; Dahlquist, J.A.; Pankhurst, R.J.; Galindo, C.; Casquet, C.; Rapela, C.W. \& Fanning, C.M. (2012). Early Carboniferous sub-to mid-alkaline magmatism in the Eastern Sierras Pampeanas, NW Argentina: A record of crustal growth by the incorporation of mantle-derived material in an extensional setting. Gondwana Research, 22(3): 992-1008. https://doi.org/10.1016/j.gr.2011.12.011

Azcurra, M.O. (2001). Geología, petrología y geoquímica de la Sierra de La Aguada, Departamento Chacabuco, Provincia de San Luis, República Argentina. Tesis de Licenciatura, Universidad Nacional de Río Cuarto, 129 pp.

Batchelor, R. \& Bowden, P. (1985). Petrogenetic interpretation of granitoid rock series using multicationic parameters. Chemical Geology, 48: 43-55. https:// doi.org/10.1016/0009-2541(85)90034-8

Bellos, L.; Castro, A.; Díaz-Alvarado, J. \& Toselli, A. (2015). Multi-pulse cotectic evolution and in-situ fractionation of calc-alkaline tonalite-granodiorite rocks, Sierra de Velasco batholith, Famatinian belt, Argentina. Gondwana Research, 27(1): 258-280. https://doi.org/10.1016/j.gr.2013.09.019

Chernicoff, C. \& Ramos, V. (2003). El basamento de la Sierra de San Luis: nuevas evidencias magnéticas y sus implicancias tectónicas. Revista de la Asociación Geológica Argentina, 58(4): 511-524.

Chernicoff, C.; Zappettini, E.; Santos, J.; Allchurch, S. \& McNaughton, N. (2010). The southern segment of the Famatinian magmatic arc, La Pampa province, Argentina. Gondwana Research, 17: 662-675. https://doi.org/10.1016/j.gr.2009.10.008

Coira, B.; Koukharsky, M.; Ribeiro Guevara, S. \& Cisterna, C. (2009). Puna (Argentina) and northern
Chile Ordovician Basic magmatism: a contribution to the tectonic setting. Journal of South American Earth Sciences, 27: 24-35. https://doi.org/10.1016/j. jsames.2008.10.002

Cristofolini, E.; Martino, R.; Otamendi, J.; Tibaldi, A.; Armas, P.; Barzola, M. \& Zambroni, N. (2015). Faja de cizalla Las Lajas: nuevos aportes al conocimiento de su geología, extremo sur de la Sierra de Comechingones, Córdoba-San Luis. Actas de la $16^{\circ}$ Reunión de Tectónica y $5^{\circ}$ Taller de Campo, General Roca-Río Negro, 28-29.

Cristofolini, E.; Otamendi, J.; Ducea, M.; Peason, D.; Tibaldi, A. \& Baliani, I. (2012). Detrital zircon $\mathrm{U}-\mathrm{Pb}$ ages of metasedimentary rocks from the Sierra de Valle Fértil: revealing entrapment of late Cambrian marine successions into the deep roots of the early Ordovician Famatinian Arc. Journal of South American Earth Sciences, 37: 77-94. https://doi. org/10.1016/j.jsames.2012.02.001

Cristofolini, E.; Otamendi, J.; Martino, R.; Tibaldi, A.; Armas, P. \& Barzola, M. (2017). Faja de cizalla Las Lajas: petrografía, estructura interna e implicancias tectónicas, extremo sur de la Sierra de Comechingones, provincias de Córdoba y San Luis. Revista de la Asociación Geológica Argentina, (in press).

Cristofolini, E.; Otamendi, J.; Walker B. Jr.; Tibaldi, A. \& Armas, P. (2014). Middle Paleozoic shear zone in the Sierra de Valle Fértil, Argentina: Records of a continent-arc collision in the Famatinian margin of Gondwana. Journal of South American Earth Sciences, 56: 170-185. https://doi.org/10.1016/j.jsames.2014.09.010

De La Roche, H. (1992). Un homologue cationique Q-A-P (quartz-feldspath alcalin-plagioclase); figure majeure de la pétrologie des roches plutóniques. C.R. Academy of Sciences París, 315(2): 1687-1693.

Debon, F. \& Le Fort, P. (1983). A chemical-mineralogical classification of common plutonic rocks and associations. Transactions of the Royal Society of Edinburgh Earth Sciences, 73: 135-149. https://doi. org/10.1017/S0263593300010117

Ducea, M.; Otamendi, J.; Bergantz, G.; Stair, K.; Valencia, V. \& Gehrels, G. (2010). Timing constraints on building an intermediate plutonic arc crustal section: $\mathrm{U}-\mathrm{Pb}$ zircón geochronology of the Sierra Valle Fértil, Famatinian Arc, Argentina. Tectonics, 29(4): TC4002. https://doi.org/10.1029/2009TC002615

El Bouseily, A. \& Sokkary, A. (1975). The Relation between $\mathrm{Rb}, \mathrm{Ba}$ y $\mathrm{Sr}$ in granitic rocks. Chemical Geology, 16: 207-219. https://doi. org/10.1016/0009-2541(75)90029-7

Fagiano, M. (2007). Geología y Petrología del basamento cristalino de las Albahacas, sur de la Sierra de Comechingones, Córdoba. Tesis Doctoral, Universidad Nacional de Río Cuarto, 380 pp.

Fagiano, M.; Otamendi, J.; Nullo, F. \& Brein, C. (1993). Geología y petrología del granito los Nogales, Achiras, Provincia de Córdoba. Actas del $12^{\circ}$ Congreso 
Geológico Argentino y $2^{\circ}$ Congreso de Exploración de hidrocarburos, Mendoza, 4: 33-44.

Frost, B.; Barnes, C.; Collins, W.; Arculus, R.; Ellis, D. \& Frost, C. (2001). A geochemical classification for granitic Rocks. Journal of Petrology, 42: 2033-2048. https://doi.org/10.1093/petrology/42.11.2033

Galliski, M. (1994). La Provincia Pegmatítica Pampeana I: Tipología y distribución de sus distritos económicos. Revista de la Asociación Geológica Argentina, 49: 99-112.

Gordillo, C. \& Lencinas, A. (1979). Sierras Pampeanas de Córdoba y San Luis. Actas del $2^{\circ}$ Simposio de Geología Regional Argentina, Córdoba, 1: 577-650.

Grosse, P.; Bellos, L.; Camilo, R.; Larrovere, M.; Rossi, J. \& Toselli, A. (2011). Across-arc variation of the Famatinian magmatic arc (NW Argentina) exemplified by I-, S-and transitional I/S-type Early Ordovician granitoids of the Sierra de Velasco. Journal of South American Earth Sciences, 32(1): 110-126. https://doi.org/10.1016/j.jsames.2011.03.014

Irvine, T. \& Baragar, W. (1971). A guide to the chemical classification of common volcanic Rocks. Canadian Journal of Earth Sciences, 8: 523-548. https://doi. org/10.1139/e71-055

Kelemen, P.B.; Hanghøj, K. \& Greene, A.R. (2003). One view of the geochemistry of subduction-related magmatic arcs, with emphasis on primitive andesite and lower crust. In: Treatise on Geochemistry 3 (Holland, H. \& Turekian, K., Eds.), Elsevier-Pergamon, Oxford, 17: 596-659.

Kretz, R. (1983). Symbols for rock-forming minerals. American Mineralogist, 68: 277-279.

Le Maitre, R.W. (1989). A classification of igneous rocks and glossary of terms. Blackwell Scientific Publications, Oxford, 193 pp.

López de Luchi, M.; Cerredo, M.; Siegesmund, S.; Steenken, A. \& Wemmer, K. (2003). Provenance and tectonic setting of the protoliths of the metamorphic complexes of Sierra de San Luis. Revista de la Asociación Geológica Argentina, 58(4): 525-540.

López de Luchi, M.; Hoffmann, A.; Siegesmund, S.; Wemmer, K. \& Steenken, A. (2002). Temporal constraints on the polyphase evolution of the Sierra de San Luis. Preliminary report based on biotite and muscovite cooling ages. Actas del $15^{\circ}$ Congreso Geológico Argentino, El Calafate, 1: 309-315.

Miyashiro, A. (1974). Volcanic rock series in island arcs and active continental margins. American Journal of Science, 274: 321-355. https://doi.org/10.2475/ ajs. 274.4 .321

Morosini, A. (2011). El granito La Escalerilla, provincia de San Luis: San Luis. Tesis Doctoral, Universidad Nacional de San Luis, 435 pp.

Morosini, A. \& Ortiz Suárez, A. (2010). La deformación Famatiniana del granito La Escalerilla, Sierra de San Luis. Revista de la Asociación Geológica Argentina, 67(4): 481-493.
Morosini, A.; Ortiz Suárez, A.; Otamendi, J.; Pagano, D. \& Ramos, G. (2017). La Escalerilla pluton, San Luis Argentina: the orogenic and post-orogenic magmatic evolution of the Famatininan cycle at Sierras de San Luis. Journal of South American Earth Sciences, 73: 100-118. https://doi.org/10.1016/j.jsames.2016.12.001

Morosini, A.; Ortiz Suárez, A. \& Ramos, G. (2009). Los Granitoides Famatinianos del sector suroccidental de la Sierra de San Luis: Clasificación y Geotermometría. Revista de la Asociación Geológica Argentina, 64(3): 253-266.

Nullo, F.; Otamendi, J. \& Fagiano, M. (1995). Geología del sur de las Sierras de Comechingones, Córdoba, Argentina. Actas do $1^{\circ}$ Encontro de Geologia Do Cone Sul, Porto Alegre, 1: 178-180.

Ortiz Suárez, A. (1988). El basamento de Las Aguadas, provincia de San Luis. Revista de la Asociación Argentina de Mineralogía, Petrología y Sedimentología, 19(1-4): 13-24.

Ortiz Suárez, A.; Grosso Cepparo, P.; Gómez Figueroa, J.; Erroz, M. \& Montenegro, T. (2009). Geología del Basamento en el extremo noroeste de la Sierra de San Luis. Revista de la Asociación Geológica Argentina, 64(3): 481-492.

Otamendi, J.; Castellarini, P.; Fagiano, M.; Demichelis, A. \& Tibaldi, A. (2004). Cambrian to Devonian geologic evolution of the Sierra the Comechingones, eastern Sierras Pampeanas, Argentina: evidence for the development and exhumation of continental crust on the proto-Pacific margin of Gondwana. Gondwana Research, 7: 1143-1155. https://doi.org/10.1016/ S1342-937X(05)71090-X

Otamendi, J.; Cristofolini, E.; Fagiano, M.; Pinotti, L. \& D’Eramo, F. (2014). Los Granitos Devónicos del sur de la Sierra de Comechingones. Relatorio del $19^{\circ}$ Congreso Geológico Argentino, Córdoba, 1: 277-291.

Otamendi, J.; Ducea, M. \& Bergantz, G. (2012). Geological, petrological and geochemical evidence for progressive construction of an arc crustal section, Sierra de Valle Fertil, Famatinian Arc, Argentina. Journal of Petrology, 53(4): 761-800. https://doi.org/10.1093/ petrology/egr079

Otamendi, J.; Fagiano, M. \& Nullo, F. (2000). Geología y evolución metamórfica del Complejo Monte Guazú, sur de la Sierra de Comechingones. Revista Asociación Geológica Argentina, 55(3): 265-279.

Otamendi, J.; Fagiano, M.; Nullo, F. \& Patiño Douce, A. (1998). Petrología y geoquímica del Complejo Achiras, sur de la Sierra de Comechingones. Revista de la Asociación Geológica Argentina, 53: 27-40.

Otamendi, J.; Nullo, F.; Fagiano, M. \& Aragón, E. (1996). Dos terrenos metamórficos y estructurales en el extremo sur de la Sierra de Comechingones, Córdoba-San Luis: algunas implicancias tectónicas. Actas del $13^{\circ}$ Congreso Geológico Argentino y $3^{\circ}$ Congreso de Exploración de Hidrocarburos, Buenos Aires, 2: 249-266. 
Pankhurst, R.; Rapela, C.; Saavedra, J.; Baldo, E.; Dahlquist, J.; Pascua, I. \& Fanning, C. (1998). The Famatinian magmatic arc in the central Sierras Pampeanas: an Early to Mid-Ordovician continental arc on the Gondwana margin. In: The Proto-Andean Margin of Gondwana (Pankhurst, R.J. \& Rapela, C.W., eds.), Geological Society London, 142: 343-368. https://doi.org/10.1144/gsl.sp.1998.142.01.17

Pearce, J.; Harris, N. \& Tindle, A. (1984). Trace element discrimination diagrams for the tectonic interpretation of granitic rocks. Journal of Petrology, 25: 956-983. https://doi.org/10.1093/petrology/25.4.956

Peccerilo, A. \& Taylor, S. (1976). Geochemistry of Eocene calc-alkaline volcanic rocks from the Kastamonu area, Northern Turkey. Contribution of the Mineral Petrology, 58: 63-81. https://doi.org/10.1007/BF00384745

Prozzi, C.R. \& Ramos, G. (1988). La Formación San Luis. $1^{\circ}$ Jornadas de Trabajo de Sierras Pampeanas: San Luis, San Luis, Actas 1: 24-26.

Rollinson, H. (1993). Using Geochemical Data: Evaluation, Presentation, Interpretation. Longman, New York, 352 pp.

Sato, A.M.; Gonzalez, P.D. \& Llambías, E.J. (2003). Evolución del orógeno Famatiniano en la Sierra de San Luis: magmatismo de arco, deformación y metamorfismo de bajo a alto grado. Revista de la Asociación Geológica Argentina, 58(4): 487-504.

Siegesmund, S.; Steenken, A.; Martino, R.; Wemmer, K.; Lopez de Luchi, M.; Frei, R.; Presnyakow, S. \& Guereschi,A. (2010). Time constraints on the tectonic Evolution of the Eastern Sierras Pampeanas (Central Argentina). International Journal of Earth Sciences, 99(6): 11991226. https://doi.org/10.1007/s00531-009-0471-z

Sims, J.P.; Stuart-Smith, P.G.; Lyons, P. \& Skirrow, R.G. (1997). Report on 1:250000 Scale Geological and Metallogenic Maps Sierras de San Luis y Comechingones, Provinces of San Luis y Córdoba. Geoscientific Mapping of the Sierras Pampeanas Argentine-Australian, Cooperative Project. Australian Geological Survey Organization, Instituto de Recursos Geológicos-Mineros, Subsecretaría de Minería, Buenos Aires.

Spear, F.S. (1993). Metamorphic Phase Equilibria and Pressure-Temperature-Time Paths. Mineralogical Society of America monograph, Washington, 799 pp.
Steenken, A.; López de Luchi, M.G.; Martínez Dopico, C.; Drobe, M.; Wemmer, K. \& Siegesmund, S. (2010). The Neoproterozoic-early Paleozoic metamorphic and magmatic evolution of the Eastern Sierras Pampeanas: an overview. International Journal of Earth Sciences, 100(2-3): 465-488. https://doi. org/10.1007/s00531-010-0624-0

Steenken, A.; Siegesmund, S.; Lopez de Luchi, M.G.; Frei, R. \& Wemmer, K. (2006). Neoproterozoic to early Palaeozoic events in the Sierra de San Luis: implications for the Famatinian geodynamics in the Eastern Sierras Pampeanas (Argentina). Journal of the Geological Society, 163: 965-982. https://doi. org/10.1144/0016-76492005-064

Steenken, A.; Siegesmund, S.; Wemmer, K. \& López de Luchi, M.G. (2008). Time constraints on the Famatinian and Achalian structural evolution of the basement of the Sierra de San Luis (Eastern Sierras Pampeanas, Argentina). Journal of South American Earth Sciences, 25(3): 336-358. https://doi. org/10.1016/j.jsames.2007.05.002

Taylor, S.R. \& McLennan, S.M. (1985). The continental crust: its composition and evolution. Blackwell Scientific Publications, Oxford, 312 pp.

Villaseca, C.; Barbero, L. \& Herreros, V. (1998). A re-examination of the typology of peraluminous granite types in intracontinental orogenic belts. Transactions of the Royal Society of Edinburgh Earth Sciences, 89: 113-119. https://doi.org/10.1017/ S0263593300007045

Von Gosen, W. \& Prozzi, C. (1998). Structural evolution of the Sierras de San Luis (Eastern Sierras Pampeanas, Argentina): implications for the Proto-Andean Margin of Gondwana. In: The Proto-Andean Margin of Gondwana (Pankhurst, R. \& Rapela, C., eds.), Geological Society of London, Special Publications, 142: 235-258. https://doi.org/10.1144/GSL. SP.1998.142.01.12

Whitmeyer, S.J. \& Simpson, C. (2004). High strain-rate deformation fabrics characterize a kilometers-thick Paleozoic fault zone in the Eastern Sierras Pampeanas, central Argentina. Journal Structural Geology, 25: 909-922. https://doi.org/10.1016/ S0191-8141(02)00118-9 


\title{
Apéndice 1
}

\author{
E. Cristofolini et al. \\ Caracterización de las rocas plutónicas de Sierra de La Aguada, Argentina.
}

\section{A) Descripción petrológica y petrográfica de detalle de las litologías que conforman la Unidad metasedimentaria.}

\section{Unidad metasedimentaria}

\section{Esquistos}

Los esquistos forman bancos elongados de $>50 \mathrm{~m}$ de potencia y $>500 \mathrm{~m}$ de longitud, los cuales exhiben tonalidades pardas claras a grises oscuras. Estas rocas también aparecen como tabiques o xenolitos que varían entre 0,2 y $10 \mathrm{~m}$ de potencia y longitudinales $>1 \mathrm{~m}$, incluidos dentro de las granodioritas (Figs. 2 y 3). Son rocas de textura granolepidoblástica dominante y porfidoblástica localizada, con fábrica esquistosa de tamaño de grano fino a medio, conformadas por la alternancia rítmica de folias finas $(<0,3 \mathrm{~cm}$ espesor) de filosilicatos (Bt-Ms; símbolos según Kretz, 1983) y cuarzo-feldespatos. En algunas variedades la esquistosidad se pierde dando paso al desarrollo de un bandeado composicional fino $(0,5$ a $0,8 \mathrm{~cm})$, que se distingue por la presencia de bandas leucocráticas compuestas por cuarzo, plagioclasa, esporádicamente feldespato alcalino, biotita, granate, epidoto y allanita, que alternan con bandas melanocráticas dominadas por biotita-moscovita (Figs. 4a, 4b y Apéndice 1). Como accesorio frecuente se destaca apatita, circón y magnetita/ilmenita. En conjunto dichas estructuras se definen en estas rocas como una foliación metamórfica penetrativa de rumbo general variante entre $\mathrm{N} 5^{\circ}$ a N $35^{\circ}$, aunque en el segmento austral de la serranía dicha estructura se dispone localmente

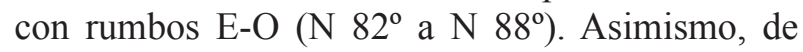
manera regular la foliación muestra un buzamiento $>52^{\circ}$ al E. Por otra parte, los esquistos exhiben internamente pliegues asimétricos de longitud de onda variable, entre 0,05 y $1 \mathrm{~m}$, conformando pliegues parásitos $\mathrm{S}-\mathrm{Z}$, con asimetría variable y vergencia oeste. Dichos pliegues exhiben planos axiales de rumbo NO-NNO y buzamientos suaves al E, cuyos ejes se encuentran buzando entre $35^{\circ}$ y $42^{\circ}$ hacia el S-SE. Además, se reconocen pliegues intrafoliares apretados e isoclinales, los cuales muestran un clivaje de crenulación de desarrollo discontinuo. Cabe destacar, que los esquistos son intruídos por diques y/o sills aplopegmatíticos de monzogranitos moscovíticos, los cuales se disponen subconcordantes a discordantes con la foliación metamórfica (Fig. 3). La paragénesis definida para los esquistos muestra la coexistencia de Bt-Ms-Qtz-Pl$\pm(K f s-$ Grt). Asimismo de manera localizada son afectados por una fuerte deformación dinámica dúctil, que desarrolla fábricas miloníticas que obliteran parcialmente la fábrica primaria.

\section{Anfibolitas}

Las anfibolitas se presentan asociadas a esquistos y/o lentes de mármoles en el extremo noroeste de la serranía, y ocasionalmente en el segmento central. Estas conforman bancos boudinados de escasa potencia, por lo general entre 20 y $80 \mathrm{~cm}$ y longitudes menores a $5 \mathrm{~m}$, mostrando morfologías subangulosas y tonalidad gris oscura a verde pálido (Fig. 2). Son rocas tenaces, de grano medio a fino, que muestran textura granoblástica interlobulada a granonematoblástica y desarrollan un bandeado composicional grosero. Dicha estructura está representada por la alternancia de bandas leucocráticas $(0,5$ a $1 \mathrm{~cm})$ de plagioclasa, cuarzo y melanocráticas 
$(0,5$ a $0,8 \mathrm{~cm})$ dominadas por hornblenda junto con tremolita-actinolita y diópsido en baja proporción, y esporádicamente titanita, allanita, epidoto, apatita y magnetita (Figs. 4c, 4d ). Esta estructura se define como una foliación metamórfica grosera, que se

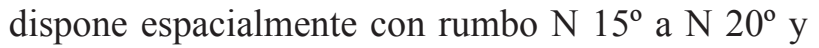
buzamientos mayores a $35^{\circ}$ al E. Asimismo, las anfibolitas muestran localmente el desarrollo de pliegues asimétricos parásitos de formas $\mathrm{S}-\mathrm{Z}$, de longitudes de onda $<50 \mathrm{~cm}$, que indican vergencia contante al oeste. Los ejes axiales de dichos pliegues inclinan $35^{\circ}$ hacia el SE. La paragénesis definida en ellas muestra la coexistencia de Hbl-Pl-Qtz $\pm(T r / A c t-D i)$.

\section{Mármoles}

Las rocas carbonáticas presentes en esta unidad se definen como mármoles serpentínicos tremolíticodiopsídicos. Estos mármoles aparecen de manera puntual en el extremo noroeste de la sierra, conformando un cuerpo ovoidal de $\sim 250 \mathrm{~m}$ de longitud y $\sim 100 \mathrm{~m}$ de potencia, dispuesto con una elongación de su eje mayor en sentido N-S (Fig. 2). Dicho cuerpo está rodeado por rocas granodioríticas, y exhibe evidencias de transformación metasomática y skarnificación, observándose una fuerte epidotización que disminuye hacia el centro del cuerpo. Los mármoles que se presentan sin transformación metasomática muestran color blanco níveo con variaciones verdes a ocres. Son rocas granudas con un tamaño de grano medio y textura granoblástica y sacaroide. Internamente el cuerpo de mármol muestra alternancia de bancos de $20 \mathrm{~cm}$ de potencia que exponen diferente grado de pureza. Asimismo, dentro de cada banco los mármoles se presentan masivos a ligeramente bandeados. Dicho bandeado metamórfico posee un ancho $<2 \mathrm{~cm}$ y se caracteriza como una foliación metamórfica, la cual se dispone espacialmente con un rumbo $\mathrm{N} 10^{\circ}$ y buzamiento de $42^{\circ}$ al E. Aunque no regularmente, el cuerpo de mármol muestra internamente pliegues intrafoliares apretados y asimétricos $\mathrm{S}-\mathrm{Z}$ con longitudes de onda $<5 \mathrm{~cm}$ y cuyos ejes axiales inclinan $\sim 42^{\circ}$ al SE. Esta roca se compone esencialmente de calcita-dolomita (Figs. 4e, 4f y Apéndice 2), en baja proporción modal tremolita-actinolita y escaso diópsido, flogopita y talco. La paragénesis definida para esta roca muestra la asociación de Cal/Dol-Tr/Act $\pm(D i)$. 


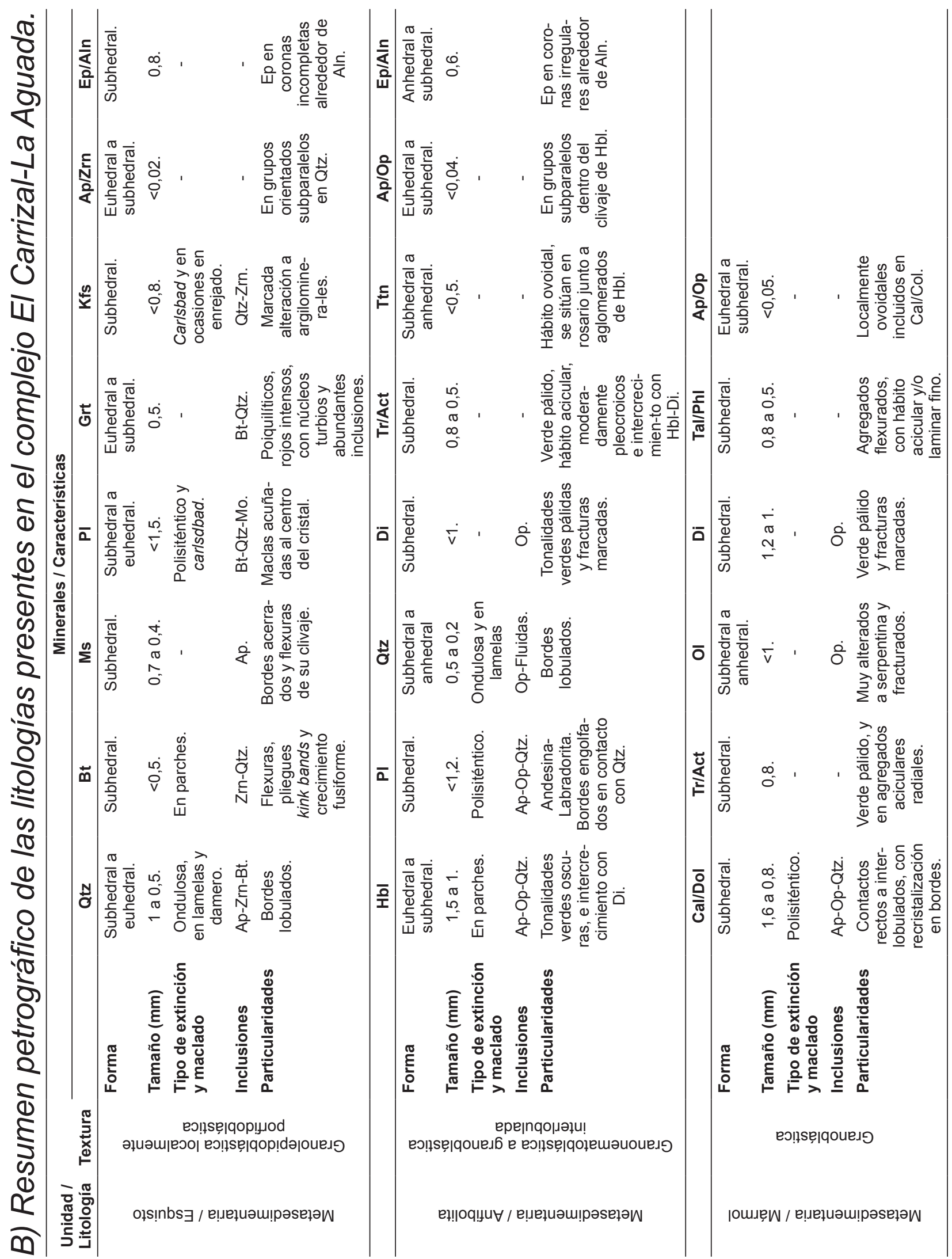




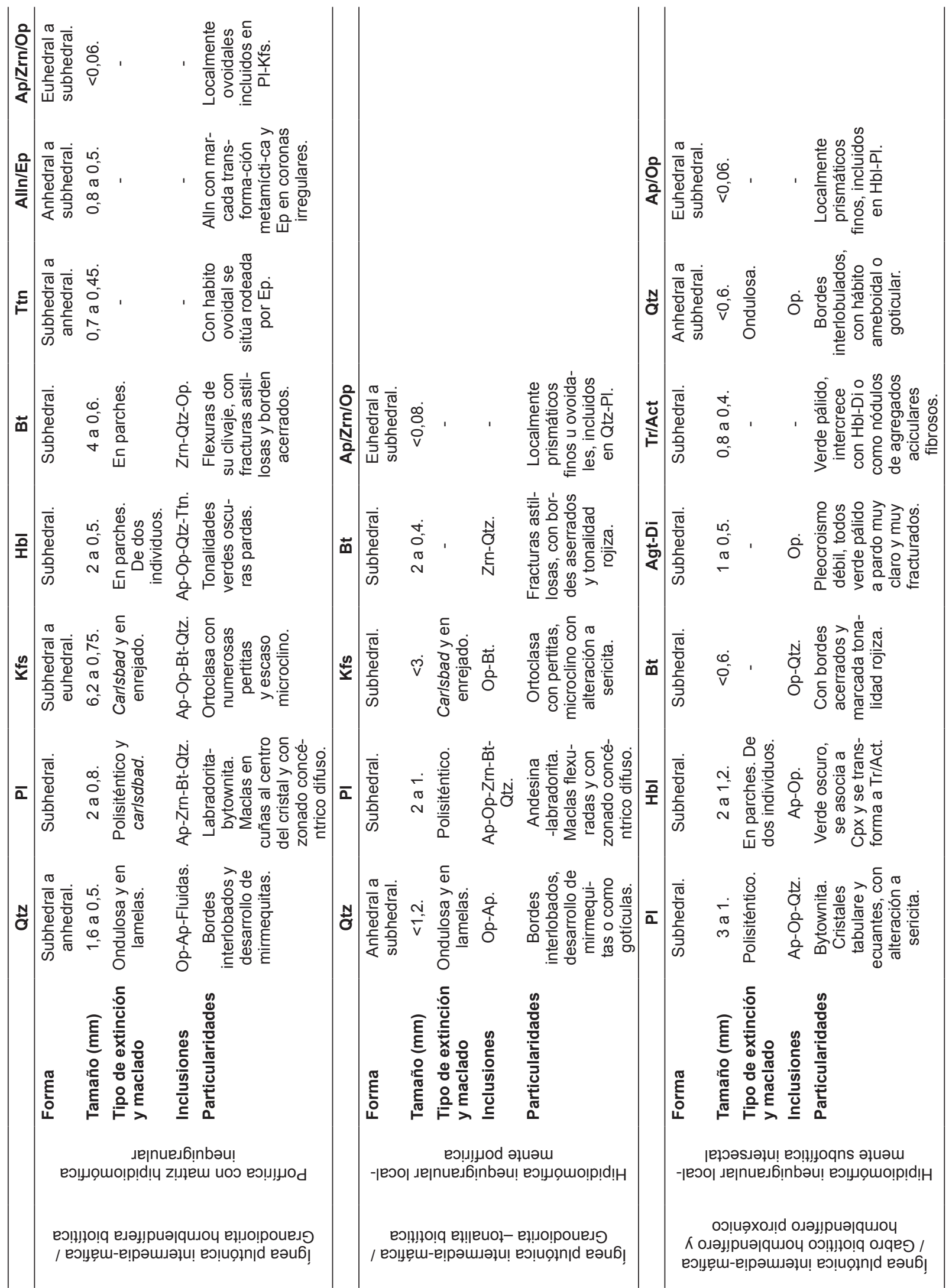




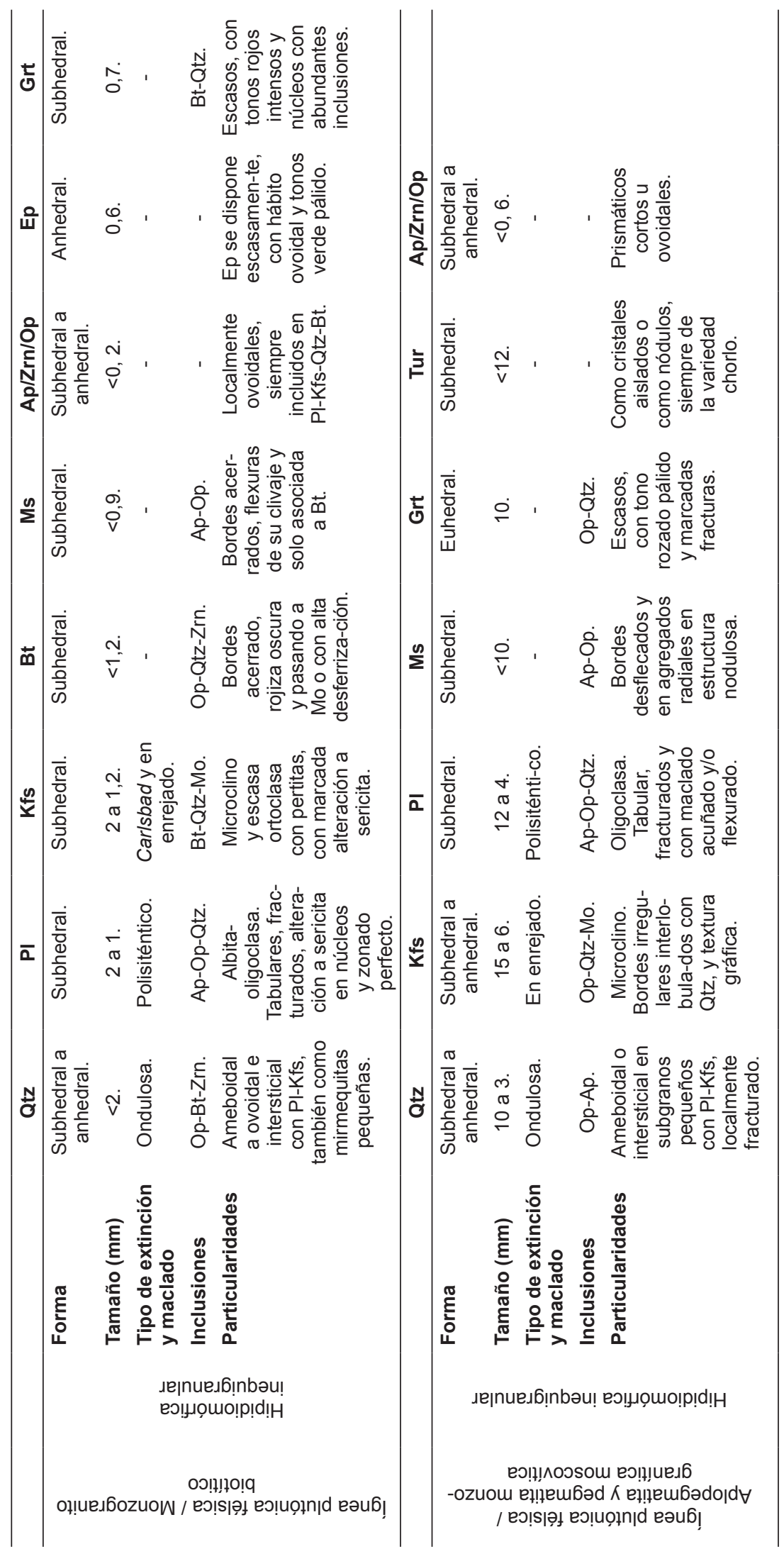

